\title{
Article \\ Coming in from the Cold: A Longitudinal Analysis of SDG Reporting Practices by Spanish Listed Companies Since the Approval of the 2030 Agenda
}

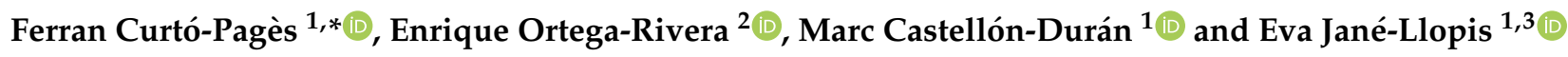 \\ 1 Esade Business \& Law School, 08034 Barcelona, Spain; marc.castellon@esade.edu (M.C.-D.); \\ eva.jane@esade.edu (E.J.-L.) \\ 2 Regional Council of Vallès Occidental, 08227 Terrassa, Spain; ortegaren@ccvoc.cat \\ 3 Department of Health Promotion, CAPHRI, Maastricht University, 6229 GT Maastricht, The Netherlands \\ * Correspondence: ferran.curto@esade.edu; Tel.: +34-932806162 (ext. 2216)
}

Citation: Curtó-Pagès, F.;

Ortega-Rivera, E.; Castellón-Durán,

M.; Jané-Llopis, E. Coming in from the Cold: A Longitudinal Analysis of SDG Reporting Practices by Spanish Listed Companies Since the Approval of the 2030 Agenda. Sustainability 2021, 13, 1178. https://doi.org/ $10.3390 /$ su13031178

Academic Editor: Ermanno C. Tortia Received: 30 November 2020

Accepted: 19 January 2021

Published: 23 January 2021

Publisher's Note: MDPI stays neutral with regard to jurisdictional claims in published maps and institutional affiliations.

Copyright: (C) 2021 by the authors. Licensee MDPI, Basel, Switzerland. This article is an open access article distributed under the terms and conditions of the Creative Commons Attribution (CC BY) license (https:// creativecommons.org/licenses/by/ $4.0 /)$.

\begin{abstract}
Despite the apparent commitment of large Spanish corporations to the SDGs, information about their documented contribution to the 2030 Agenda is still scarce. This article aims to explore this gap by investigating the extent to which Spanish listed companies have been reporting on the SDGs since the approval of the 2030 Agenda. The paper contributes to the country-level analysis of SDG reporting by performing a longitudinal analysis over the 4-year period encompassing 2016 to 2019. It contributes to management science by assessing Corporate Sustainability performance through adherence to the SDGs and testing what the facilitators of SDG reporting have been during the first 4 years since the adoption of the 2030 Agenda. Findings reveal a low commitment of Spanish listed companies to sustainability reporting. Nevertheless, they also uncover how those companies that publish non-financial reports are increasingly reporting on the SDGs. Additionally, there is also a growing tendency among CEOs to mention the SDGs in their letters to stakeholders. Furthermore, a positive link is established between the adoption of GRI reporting standards or being a signatory of the UN Global Compact and SDG reporting. Similarly, those companies that publish Integrated Reports are more likely to consider the SDGs in their disclosures than those that publish Standalone Reports or Annual Reports. Nonetheless, there is a growing tendency to gravitate from producing Integrated Reports to producing Annual Reports. Owing to the breadth of these results and their relevance to academics and practitioners alike, this study can help build future evidence-based accountability literature and policy on the SDGs at the Spanish and European levels.
\end{abstract}

Keywords: corporate sustainability; sustainable development goals; Non-Financial Reporting; UN Global Compact; GRI; Spanish listed companies

\section{Introduction}

The United Nations resolution of September 2015 "Transforming our world: the 2030 Agenda for Sustainable Development" establishes the 17 Sustainable Development Goals (SDGs), which seek, with the motto "no one left behind", to eradicate poverty, reduce inequality and care for the environment [1]. The 17 SDGs contain 169 specific targets, and combine several dimensions of sustainable development: economic, social, environmental, and governance. In contrast to previous state-centred, negatively framed sustainability agreements aimed at "developing countries" such as the Millennium Goals [2], this global agenda stands for a global co-responsibility model which is neither based upon the "NorthSouth" divide nor on the "Central-Peripheral" dichotomy [1]. Some authors have seen the 2030 Agenda as a model of global governance by goal-setting [3]. In this context, business organizations are called to play a critical role for sustainable development [4]. The call for businesses is based on two premises: The economic opportunity the SDGs represent [5-8] and the co-responsibility of companies in becoming development agents 
and contributing to a better future $[9,10]$. Some researchers have also claimed that business responsibility with sustainability (and therefore, with the SDGs) is no longer a choice, but an imperative [11,12].

Since the approval of the 2030 Agenda in 2015, multiple initiatives have flourished from international organizations, think tanks, and consultancy firms to facilitate the understanding of the SDGs by private companies engaging with the 2030 Agenda $[13,14]$. Similarly, several approaches have emerged to help report businesses' contributions to the SDGs $[15,16]$.

In the academic sphere, interest in the SDGs has significantly grown within the last few years. Recently, three special issues on other journals have focused on the business contribution to the SDGs (one in Transnational Corporations and two in the Academy of Management Discoveries) and several academic conferences worldwide have focused on the contribution of the business world to the 2030 Agenda [17]. The SDGs have been included in the corporate sustainability literature from several perspectives: Some authors have developed propositions to help explain how Multinational Enterprises' (MNEs) engage with the SDGs [2]; other researchers have studied how the SDGs have been adopted as an inspirational model to design sustainability business models [18]; and some academics have also considered how the SDGs can become a way for businesses to legitimize their practices in the eye of their stakeholders [19] through the further development and assessment of their corporate sustainability [20]. This paper fits within the last stream of literature that was mentioned and considers SDG reporting a form of sustainability reporting that involved the practice of reporting publicly on how an organization addresses the SDGs, no matter the type of non-financial reports used for this purpose.

Despite the inherent tensions present in the notion of sustainable development (accomplishing economic development, respect to the environment, and social equity) [21], since 2015, the 2030 Agenda has become the most current and accepted framework to achieve such development [22]. Hence, it seems reasonable that management science researchers considering current practices on sustainable development should investigate how the private sector has been contributing to the SDGs. Being the 2030 Agenda a global imperative, Tsalis et al. [23] claim that companies must adapt their corporate sustainability management systems to fulfill the requirements of this global action plan for sustainability". However, until today the academic sphere seems to have paid little attention to how SDG reporting can become a tool for business accountability [24]. Academic papers in SDG reporting are scarce and, to our knowledge, no country-level longitudinal analysis on the evolution of SDG reporting has ever been performed. This paper aims to fill this gap by studying the extent to which Spanish listed companies have been reporting on the SDGs since the approval of the 2030 Agenda. Following Sierra et al. [25], we assert that Spain is an interesting case-study as it is one of the most committed European countries to the presentation of non-financial information, with national companies achieving high scores in sustainability indexes [26]. This study also attempts to identify significant sectorial differences with regards to Spanish listed companies' explicit commitment to the SDGs. Furthermore, our article considers the connection between SDG reporting and the use of the Global Reporting Initiative (GRI) framework, as well as the relationship between SDG reporting and being a signatory of the Spanish Network UN Global Compact. Finally, through our research we explore the likeliness of SDG reporting in light of the different types of reports companies use to disclose non-financial information, namely: Sustainability Reports, Integrated Reports, CSR Reports, Annual Reports, and Non-Financial Statements.

In line with recently published research $[27,28]$, this article attempts to answer the following main research question: "Do Spanish listed companies report on the SDGs?" Rather than focusing only on one year worth of disclosures, our research takes a four-year longitudinal perspective aiming to paint a broader picture on SDG adoption and to uncover evolutionary patterns on how companies report their contribution to the 2030 Agenda. Secondary questions are formulated to enable the study of any relevant visible trends in SDG reporting: (1) "What has been the evolution of SDG reporting since the approval 
of the 2030 Agenda?"; "What are the most commonly mentioned SDGs in the reports?"; "Are there relevant sectorial differences in this evolution?"; "Is there a positive relationship between the use of GRI standards and SDG reporting?"; "Are members of the UN Global Compact more likely to report on the SDGs?"; "Have the type of reports used by companies to disclose SDG information affected their disposition to report on the SDGs?"

To answer these questions, this paper considers all non-financial reports published by Spanish listed companies for the fiscal years 2016, 2017, 2018, and 2019. As previously introduced, these can be of five types: Annual Reports, CSR Reports, Sustainability Reports, Integrated Reports, and Non-Financial Statements. Spanish listed companies make up the sample of our analysis, based on the understanding that, as Public Interest Entities (PIEs) and leading companies on economic-financial performance, they are most likely to report on sustainability-related issues. Although reporting on the SDGs is not mandatory by Spanish Law, the SDG framework is the first reporting framework proposed by law within the different reporting frameworks mentioned by law 11/2018.

Our final sample for the 4 chosen years is composed of 58 listed companies belonging to the Bolsas y Mercados Españoles (BME, Spanish Stock Exchanges and Markets), headquartered in Spain, and that produced non-financial reports for all 2016, 2017, 2018, and 2019. Accordingly, the breadth of our analysis includes a total of 232 documents. The results of our research suggest that there has been a substantial increase in SDG reporting among these companies since the approval of the 2030 Agenda.

The rest of the paper is structured as follows: Section 2 summarizes the literature review related to the hypothesis. Section 3 details the longitudinal analysis methodology including data-selection, data-extraction, and data-processing. Section 4 presents the results describing the statistical data and summarizing how our research constructs are related to each other. Section 5 discusses these results and resolves the hypotheses. Finally, Section 6 summarizes our findings and considers their relevance to the 2030 Agenda and business sector Non-Financial Reporting.

\section{Literature Review and Hypotheses Building}

\subsection{Sustainable Development and Corporate Sustainability}

The climate emergency humanity is facing today (in terms of loss of biodiversity, increase in climate extreme events, resource depletion, and global warming) is the result of the "Great Acceleration" in our global socioeconomic system that started in the second half of the 20th century [29]. This concept refers to the joint effects of the exponential growth of the global population (from 2.6 billion people in 1950 to 7.7 billion in 2020) and the high dependency on natural resources of our current production and consumption patterns [30]. In 1972, the Club of Rome warned that humanity had to establish limits to its economic activity if it wanted to conserve its productive capacity, well-being, and ecological resources [31]. Since then, the scientific community has warned multiple times that the existing growth model entails serious risks for the planet and humanity [32]. Despite these messages, the environmental situation has only gotten worse.

The notion of 'sustainable development' was conceived to find alternative paths to socioeconomic progress that were not so dependent on the limited natural resources accessible on Earth and that could guarantee the wellbeing of future generations. The term was officially coined in the Brundtland Report [33] to refer to "the idea that human societies must live and meet their needs without compromising the ability of future generations to meet their own needs". Since then, both societal expectations with regards to businesses and the general call for a greater involvement of the business community with sustainable development has grown steadily. This can be explained through the appearance of multiple trends such as the increase of the relative power of private corporations compared to the public sector [34]; the 'blurring boundaries' between the roles of public and private actors [35]; the "ever-increasing complexity and transboundary nature of sustainability issues which have led to a shift in standing and weight of the involved and affected parties" [36]; 
the increasing pressure of consumers [37] and investors [38]; and the increasing regulation and political pressure on private performance [39].

Corporate Sustainability has become the main field of study to consider how business action can contribute to sustainable development by keeping up with all these trends [40]. As a concept, Corporate Sustainability links organisational activities to outcomes at the societal and environmental level and demands business firms focus on improving the general welfare of society [41]. Given the long-term orientation often attributed to Corporate Sustainability, it sometimes colludes with the short-term focus of the corporate world traditional modus operandi [42]. Moreover, Corporate Sustainability is inherently paradoxical, as it must deal with the underlying tensions that result from the willingness to satisfy social, environmental, and economic concerns altogether, considering the different temporal and spatial scales where they reside [21]. The concept is closely related to the traditional concept of sustainable development, as shown by Dyllick and Hockerts' [43] definition of Corporate Sustainability as "meeting the needs of a firm's direct and indirect stakeholders without compromising its ability to meet the needs of future stakeholders as well" $[42,44]$.

Despite the unquestionable connection between the notions of sustainable development and Corporate Sustainability, management science has not started to approach them from an integrated and holistic perspective until recently [40]. Before the 2010s, different research fields such as 'environmental management', 'social issues in management', or 'development studies' coexisted in a rather isolated way, despite Elkington's early integrating perspective of the triple bottom line [45]. Although the different streams of academic literature still coexist, a certain convergence has taken place in the last decade, as the notion of sustainable development has increasingly been placed both in the public agenda and the academia and management practice [40].

An important turning point in this process of convergence between the notions of sustainable development and Corporate Sustainability was the approval, in 2015, of the Paris Agreement and the 2030 Agenda. Both international agreements establish a holistic and comprehensive interpretation of sustainable development and provide innovative frameworks for action [46]. The 2030 Agenda makes an explicit call to the business community to take joint responsibility for the SDGs and to take advantage of the business opportunities they offer [6]. Since 2015, business associations, investment funds, and leading corporations all over the world have been involved in the discussions at multiple levels of governance, and a "post-2015 business engagement architecture" has been structured [40]. Many actors in the global policy arena have recently declared the need to move from shareholder capitalism to stakeholder capitalism and have advocated for a greater involvement of the business sector with the planet and the common good [47-49].

These changes in global policy have led to the emergence of several frameworks for Corporate Sustainability priority setting and measurement, developed by leading institutions in the field such as the Global Compact, the World Business Council for Sustainable Development (WBCSD), and the Global Reporting Initiative (GRI). Furthermore, new regulations aligned with sustainable development, such as the EU Directive on Non-Financial Reporting have also been approved. Directive 2014/95/EU establishes the minimum requirements for companies considered Public Interest Entities to disclose non-financial information on how they addressed environmental, governance, and social topics during the last economic exercise. This involves corporations producing a yearly non-financial report that contains information on relevant policies, due diligence processes, and stakeholder management. The report must be made available to the public and to public institutions that desire to scrutinise the company's activities. The academic agenda has been influenced by these changes: Within the field of corporate sustainability, the evolution of the concept of sustainability has influenced corporate Sustainability Reporting [23]. 


\subsection{Sustainability and Sustainability Reporting}

Today, the success of any given company greatly depends on how the business matches the demands of its stakeholders [50]. Sustainability reporting is one of the tools companies have more readily at their disposal to show their stakeholders that they are indeed responding to their needs and creating solutions that have a value for society and the planet at large [51]. Furthermore, Sustainability reporting is being increasingly recognised as a crucial element for corporate sustainability [52]. The concept can be defined as an organisation's practice of reporting publicly on its economic, environmental, and/or social impacts, and, hence, its contributions, positive or negative, to sustainable development [53].

Three historical stages of Sustainability Reporting have been identified by Fifka [54]: The 1970s, when social reports complemented financial reporting in developed countries; the 1980s, when environmental issues gained importance (with a focus on waste generation and emissions) [55]; and the 1990s, when the GRI was created and started promoting a sustainability reporting model including environmental and social issues [56]. SDG reporting fits into the latest stage of the business sustainability reporting historical evolution. Both the broad focus and interconnectedness of the 17 SDGs [2] and the appeal they make to public and private organizations alike make them a suitable framework to align all the players in the global arena around a common framework for sustainable development. From a general perspective, Bebbington and Unerman [24] have attributed to the SDGs the potential to inform and advance research and practice on sustainability accounting and reporting on the basis of their coherence and broad acceptance.

From the management science perspective, the measurement and disclosure of Corporate Sustainability represents one of the guiding pillars of Corporate Sustainability management [57]. Moreover, corporate accountability and non-financial disclosure conform currently the most comprehensive path to materialising the connection and integration of sustainable development and Corporate Sustainability [40]. Corporate accountability and non-financial disclosure are strongly conditioned by the different legal frameworks in which companies operate. Hence, the voluntarily vs. mandatory debate has become a key theoretical perspective when approaching this topic [58]. Similarly, the use of different measurement standards and the variety in the types of report used by companies to refer to these disclosures have become important aspects in the academic field of sustainable development [56].

\subsection{The Growing Interest in SDG Reporting in the Business Sector}

SDG reporting in the business sector has its origins in the global policy arena. SDG 12 target 6 of the 2030 Agenda "encourages companies, especially large and transnational companies, to adopt sustainable practices and to integrate sustainability information into their reporting cycles". In 2018, the UN Global Compact launched an Action Platform ("Reporting on the SDGs") aimed at integrating the SDGs into the reporting practice [59]. Similarly, the UNCTAD has recently published the document Guidance on Core Indicators for Entity Reporting on Contribution Towards Implementation of the Sustainable Development Goals [60]. In Europe, the EU Directive 2014/95/EU on Non-Financial Reporting establishes an unprecedented political commitment to the topic by including the SDGs as an important reporting framework to be considered by Public Interest Entities in their non-financial reports.

In the recent World Economic Forum International Business Council (IBC) in Davos (2020), a report was issued which proposes a "common, core set of metrics and recommended disclosures that private sector companies could use to align their mainstream reporting" [61]. The report, developed by four large consulting companies (Deloitte, EY, KPMG, and PwC), proposes metrics aligned with the essential elements of the SDGs organised in four pillars: Principles of Governance, Planet, People, and Prosperity. Consulting firms have also issued reports individually, proposing quality criteria to assist organizations in SDG reporting [62,63].

In addition to the policy arena and the business sphere, traditional Non-Financial Reporting Organizations such as the GRI or the International Integrated Reporting Council 
(IIRC) have also published guidelines for companies to understand how to report on the SDGs [64,65]. Leading accountancy bodies around the world have also discussed how accounting professionals can contribute to the SDGs [66]. Finally, the World Business Council for Sustainable Development has published Reporting Matters, a document in which sustainability reports from its member companies are analysed against a set of comprehensive indicators, and a spotlight is placed on the SDGs [51]. In essence, since the approval of the 2030 Agenda, public pressure, government regulation, and investor scrutiny have converged leading to an explosion of information requests and reporting approaches to satisfy stakeholder needs [51]. In this context, sustainability reporting is receiving growing attention in business and academia [67].

From management science, some researchers have started describing the actual business contribution to the SDGs. Rosati and Faria [17] found that only 67 out of the 408 organizations included in their sample (16\%) addressed the SDGs in the Sustainability Reports published in 2016. Focusing on the social role of finances, Schramade [68] argued that the SDGs should be linked to specific incentives to influence the investors' choice. Van Zanten [2] made an exploratory survey with 81 European and North American Financial Times Global 500 companies and concluded that MNEs engage more with SDG targets that are actionable within their (value chain) operations than those outside of it, and more with SDG targets that "avoid harm" than those that "do good". Izzo [27] concluded that most Italian listed companies started to report information about the SDGs in 2016. Despite the limited number of companies analysed, these initial findings do not show a positive relation between belonging to a specific sector and reporting on the SDGs.

While the number of academic papers describing corporate SDG reporting is increasing steadily, descriptive longitudinal country-analyses are still needed to provide a substantial basis for understanding companies' actual contribution to the SDGs over time and establishing sectorial patterns of evolution. To our knowledge, such longitudinal analysis does not exist for Spain, or for any other EU member state. This article will attempt to fill this gap in the available academic literature by conducting an analysis to identify significant sectorial differences for SDG reporting, and contribute to the assessment that certain sectors are more prone to report on the 2030 Agenda [69].

To perform such an analysis, it is necessary to take into account one of the most important turning points in the evolution of sustainability reporting in Spain in the 2010s: the transposition of Directive 2014/95/EU. In Spain, the first transposition is to be found in Royal Decree-Law 18/2017, which was published with over a year of delay in relationship to the dates marked by the EU. This first transposition was quasi-literal. It was the year after that more comprehensive Law 11/2018 was published in the Official State Journal on 29 December 2018 and applied from January 2018. This was2 years and 3 months after the approval of the 2030 Agenda. While the law may have had an impact on the quality and/or quantity of SDG reporting, the assessment of such impact should consider the detail regarding the different reporting specifications considered by the law (environmental matters, social and employee-related matters, respect for human rights, anti-corruption, and bribery matters). Performing such an assessment would divert us from the goal of this research. Hence, the influence of the Directive will not be tackled specifically, although attention will be paid to the presence of differential elements that may serve to justify 2018 as a turning point in time. Thus, the first hypothesis of our research will solely be built on the idea that the 2030 Agenda has gained prominence in the business sector within the last 4 years. The authors consider that Spanish listed companies have been increasingly reporting on the SDGs since 2016.

Hypothesis 1 (H1). SDG reporting among Spanish listed companies has increased since the first year after the approval of the 2030 Agenda. 


\subsection{Membership to Global Compact as an Institutional Driver for SDG Reporting}

Several authors have approached the external and internal factors that influence an organisation's decisions with regards to Sustainability Reporting [67]. Owing to the different institutional characteristics of each state (political and legal system, sociocultural norms, etc.), a company's country of origin is deemed an important determinant of the success of sustainability reporting [70]. Along this line, Biermann et al. [3] defended that the success of actions supporting the SDGs depend on several institutional factors such as the extent to which countries concretely formalize their commitments to the SDGs, or their ability to turn global challenges into national issues. Similarly, Rosati and Faria [17] showed that countries with higher levels of climate change vulnerability, national corporate social responsibility, or long-term orientation, etc. are more likely to be home to organisations reporting on the SDGs.

Since the Global Compact of the UN is one of the main amplifiers for the involvement of businesses in the Agenda 2030 worldwide, one could reasonably argue that it constitutes one of these "external factors" that can affect the degree of SDG disclosures made by companies. In fact, Van der Waal et al. [71] analysed sustainability reports of a sample of the two thousand largest stock listed corporations worldwide and concluded that, while corporate involvement with the SDGs is still very limited overall, Global Compact membership is the only factor which is consistently highly significant. This finding, they argue, may be connected to countries that have active local Global Compact networks. From a different perspective, Chen and Bovain [72] found that Global Compact membership has a significant effect on the inclusion of measurable CSR performance indicators related to the environment and workers by companies.

Following the steps of the aforementioned authors, this paper aims to assess whether Spanish listed companies' membership to the United Nations Global Compact Network has a positive influence on SDG reporting. Thus, we propose the following hypothesis:

Hypothesis 2 (H2). Companies that belong to the Global Compact are more likely to report on the SDGs than companies that are not.

\subsection{The Adoption of GRI Standards as a Determinant of SDG Reporting}

The Global Reporting Initiative (GRI) was founded in 1997 as a joint initiative of non-profit institution Ceres, the Tellus Institute, and the UN Environment Programme. The organisation has since held to its main goal: to create accountability mechanisms for companies to communicate on their environment, social, governance, and economic performance. The entity's first set of guidelines (G1) was published in 2000 and, since then, the original version of the standards has been revised thrice. In 2020, the company continued to update its framework contents (i.e., with indicators on waste).

Today, the Global Reporting Initiative is considered the leading authority world-wide on sustainability reporting. The GRI Standards guidelines are probably the most adopted Non-Financial Reporting framework worldwide [63,73]. Even as other organisations have taken a share of the Non-Financial Reporting market, the GRI framework remains the most popular among companies worldwide.

Since their creation in 1997, these standards have been adopted by several organizations in the public and the private sectors [74]. In the 2018 report "SDGs. Analysis of Goals and Targets" [75], the GRI asserts that its standards have become inextricably linked to SDG reporting. This document links all SDGs and their specific targets to GRI indicators and, thus, can be considered a guide for companies to report their contributions to Agenda 2030 in their Non-Financial Reports. Such an integrated approach provides a solid basis for companies to communicate with their stakeholders on the SDGs.

Before the approval of the 2030 Agenda, the use of the GRI indicator framework by companies was already considered a determinant of the quality of their sustainability reporting. Hence, Dilling [76] analysed whether best performing corporations prepare their Sustainability Reports according to the GRI guidelines. Skouloudis et al. [77] similarly 
noted the influence of the GRI indicators on the quality and quantity of Non-Financial Reporting. Efforts were also made by other researchers to study the impact of the GRI indicators in the case of specific industries [78].

To our knowledge, since the approval of the 2030 Agenda, only Pizzi et al. [79] have conducted an analysis to assess whether GRI adoption is positively connected to the quality of SDG reporting. Following their steps and considering the relevance of integrating NonFinancial Reporting frameworks with the SDGs [80], we propose the following hypothesis:

Hypothesis 3 (H3). Companies that adopt a GRI framework for reporting are more likely to report on the SDGs than companies that do not.

\subsection{The Type of Report as an Organizational Determinant of SDG Reporting}

The predominant practice in sustainability reporting is either to publish a Standalone ESG (Environmental, Social, Governance) report as an addendum to the Annual Report or to incorporate a separate chapter in the Annual Report [81]. The Annual Report is a mandatory instrument used by companies to communicate their economic results to a broad range of stakeholders [82]. Over the last decade, the IIRC and the GRI frameworks have become more prominent among corporations, and other types of reporting have also become popular to address sustainability issues, namely: Integrated Reports (IR), which combine financial information with ESG information in a concise manner [83]; and "Standalone" Sustainability Reports, which generally focus specifically on disclosing sustainability strategies and ESG matters. These receive different names: 'Sustainability Reports' (SR), 'CSR Reports' (CSR), 'Environmental Reports', and 'Corporate Citizenship Reports' [27]. All these types of reports, especially the IR, have gained momentum over the last few years owing to concerns on the reputations of some Multinational Corporations [84]. With the approval of the European Directive 2014/95/EU on Non-Financial Reporting, yet another type of report was added to this list of sustainability reports: The Non-Financial Statement. This is the name given by the Directive to a document that must include all the mandatory disclosures related to environmental matters, social and employee-related matters, respect for human rights, anti-corruption, and bribery matters of companies deemed Public Interest Entities by the European Commission.

Several researchers have studied how the typology of a report can affect its contents and quality [85]. The literature suggests that the publishing of standalone reports might be associated to a higher commitment to sustainable development [86]. Focusing on the sustainability reporting of Spanish listed companies between 2013 and 2015 (previous to the approval of the 2030 Agenda), Romero et al. [87] found that Sustainability Reports provide higher quality information than Integrated Reports and these, in turn, provide higher quality information than Annual Reports.

The typology of reports has recently been considered an organizational determinant of SDG reporting [88] In their analysis of the organizational determinants of SDG reporting, Pizzi et al. [69] concluded that there is a positive connection between standalone reports and Integrated Reports and the quality of SDG disclosures. Similarly, Izzo et al. [27] found that Italian companies prefer using Non-Financial Statements and Sustainability Reports to disclose information about their commitments to the SDGs. Finally, the same authors have recently provided empirical evidence on the positive connection between the use of Integrated Reporting and SDG disclosures [89].

It should be considered whether this trend also holds in the case of Spanish listed companies. Thus, this article will explore how the type of report published by companies affects the quality of their reporting on the SDGs. Hence, our fourth hypothesis is:

Hypothesis 4 (H4). Companies that publish an Integrated Report or standalone report are more likely to report on the SDGs than companies that publish an Annual Report. 


\section{Materials and Methods}

This section outlines the methodology followed to undertake the longitudinal study on SDG reporting by companies during 2016, 2017, 2018, and 2019. The first sub-section describes how the sample was selected, the second outlines the data sources and summarizes the data-collection process, and the third explains, how the data was processed and analyzed. We adopted a mixed methods approach based both on a content analysis and descriptive statistical analysis of the data gathered. In the mixed methods research, content analysis is a well-established technique that allows answering research questions or test hypotheses addressing relationships between independent and dependent variables constructed from qualitative data sets $[90,91]$.

\subsection{Inclusion-Exclusion Criteria and Sample Selection}

Inclusion/exclusion criteria to compose the final study sample were defined as follows:

- Companies listed in the Madrid Stock exchange (a surrogate of the operator Bolsas y Mercados Españoles-BME).

- Companies headquartered in Spain.

- Companies that had Non-Financial Reports for each of the years under study (20162019).

The first step toward selecting our sample was to obtain the names of all listed companies for 2016, 2017, 2018, and 2019. The number of relevant organizations for each year was 175, 169, 165, and 160, respectively. These fluctuations are owing to mergers and acquisitions, as well as yearly inflows and outflows of organizations in the stock market.

Companies that were not headquartered in Spain were excluded from the sample. Inclusion criteria was defined as companies headquartered in Spain as the research aimed to ascertain overtime the impact of potential policy changes in the country discussed at the time. This reduced our sample by 27 entities in 2016, 27 in 2017, 27 in 2018, and 26 in 2019.

This exclusion was further complemented by excluding companies that were deemed "inactive" (i.e., had not presented to the authorities a part or the totality of the relevant fiscal data for any of the studied years). There were nine of these companies in 2016, 1 in 2017, 1 in 2018, and 1 in 2019.

Then, we only considered companies that had published a Non-Financial Reporting (i.e., Integrated Report, Sustainability Report, CSR Report, Annual Report, and/or NonFinancial Statement) for each of the 4 years, excluding the sample companies that did not issue a report on 1 or multiple years, further reducing the sample by 69 companies in 2016, 65 in 2017, 41 in 2018, and 36 in 2019. It is noteworthy that less companies were excluded with every passing year since more companies reported non-financial data respective to the previous exercise (i.e., more companies reported in 2018 than in 2017).

At the end of this process, our sample included 58 companies that simultaneously fulfilled all criteria for 2016, 2017, 2018, 2019. The sample selection that was just detailed is summarised in Table 1.

Table 1. Sample selection.

\begin{tabular}{|c|c|c|c|c|}
\hline Selection Criteria & 2016 & 2017 & 2018 & 2019 \\
\hline Listed companies Bolsa de Madrid (BME) & 175 & 169 & 165 & 160 \\
\hline Inflows & / & 4 & 4 & 1 \\
\hline Outflows & / & -10 & -8 & -6 \\
\hline Companies not headquartered in Spain & -27 & -27 & -27 & -26 \\
\hline Inactive companies headquartered in Spain & -9 & -1 & -1 & -1 \\
\hline Companies that did not publish any reporting document during the fiscal year & -69 & -65 & -41 & -36 \\
\hline Companies that did not fulfil all criteria for every relevant year & -12 & -12 & -34 & -34 \\
\hline Final sample & 58 & 58 & 58 & 58 \\
\hline
\end{tabular}




\subsection{Expansion of Data Sources of the Selected Sample}

The data-collection process was based on a search for extra-financial reports in which documents with a broader depth of non-financial information were prioritised. The procedure was divided in the following steps: First, the researchers strived to identify an Integrated Report (IR) for each company. This type of document is defined as a communication instrument put forth by the International Integrated Reporting Council (IIRC) to disclose, in a succinct and efficient manner, information on the strategy of organizations, their corporate governance, environmental, social and economic performance, and future perspectives [83]. Should this report not be available, researchers attempted to find a CSR or a Sustainability Report for that year. These two documents provide similar data to the Integrated Report but are less detailed in matters to do with corporate strategy and the integration of reporting frameworks. When these were not found, searches were defined to identify the Annual Report, which is an instrument of mandatory use in Spain for listed companies to communicate their economic performance, with a dedicated section on strategy and CSR (i.e., which does not become an independent document, as would be the case for a CSR or Sustainability Report, as well as an Integrated Report). If an Annual Report was not available either, researchers attempted to find a Non-Financial Statement. These reports became mandatory for listed companies in 2018 as a result of the transposition of the EU Directive 2014/95/EU (in Spain, the first transposition of the directive is to be found in Royal Decree-Law 18/2017. The year after, Law 11/2018 was published in the Official State Journal on 29 December 2018 and amplified the scope of reporting for Spanish PIEs from January 2019 onwards). Generally, Non-Financial Statements are integrated in other extra-financial reports of the types that have already been described in this section. Nonetheless, often they may be presented as a standalone document. Should none of the aforementioned reports be available for any given company any given year, the organization was discarded from the sample.

For each of the 58 companies in our sample we conducted a content analysis of four Non-Financial Reports, with one considered per year. Three hundred and forty-five reports were identified as relevant and prioritised based on which document is to be published first each year and by each organization. This process led to a total of 232 documents published in 2016, 2017, 2018, and 2019. The reports used for our research were obtained from the official websites of the companies included in the sample. The information stratified by the report type is shown in Table 2. In addition, Appendix A (Table A1) shows, at an aggregate level, the different reporting typologies of our sample of companies. As can be seen, between 2016 and 2019, only 14 of the 58 companies present a single reporting document typology (specifically, 11 the Integrated Report and three the Sustainability Report), while the majority (44) present different ones, with Integrated Reports being the predominant typology.

Table 2. The typology of reports analyzed for the period ranging between 2016 and 2019.

\begin{tabular}{ccc}
\hline Reporting Document & Number & $\%$ \\
\hline Integrated Report & 138 & $59.5 \%$ \\
Sustainability Report & 15 & $6.5 \%$ \\
CSR Report & 39 & $16.8 \%$ \\
Annual Report & 29 & $12.5 \%$ \\
Non-Financial Statement & 11 & $4.7 \%$ \\
Total & 232 & $100 \%$ \\
\hline
\end{tabular}

\subsection{Coding System and Data Extraction}

To study the variations in SDG reporting of Spanish listed companies between years 2016 and 2019, a longitudinal approach was adopted undertaking content analysis of the selected reports. Content analysis is an investigation method widely used in business research. It allows researchers to infer conclusions from valid and replicable data gathered from writings or visual representations [92]. More specifically, we used a quantitative 
approach, identifying and quantifying certain content or words in the text [93]. A similar approach is developed by Izzo, Strologo et al. [89].

The data was manually coded following a standard and reproductible protocol. First, we categorized the type of report defined as: Integrated Report, Sustainability Report, CSR Report, Annual Report, and Non-Financial Statement. To address each of the questions raised in our hypotheses the following variables (from here onwards defined as our dependent variables) were coded from the documents. All the variables were coded with " 1 " if present and " 0 " if absent:

- Explicit reference to the SDGs in the reports.

- Presence or not of SDG mentioning in the letter of president or in the letter of CEO, a report prologue which is customarily found at the start of most extra-financial reports in Spain [89].

- Explanation (or not) of the relevant measures and actions companies are undertaking in support of the specific Goals they are working on (17 Goals).

Independent variables included whether the companies reported in accordance to Global Reporting Initiative (GRI) to allow us to study whether the adoption of such framework is positively associated to the quantity of reporting on the SDGs. Similarly, we coded whether the studied entities were members of the UN Global Compact, in an effort to further consider other variables that might influence reporting on Agenda 2030. A condensed version of the codebook is reported in Appendix B (Table A2).

The coding process was carried out separately by two qualified members of the research team, with training on content analysis and statistical analysis. Coding was performed annually in parallel by both researchers dividing the companies in the sample between them in alphabetic order. A specifically designed training was furthermore followed by both coders to master the use of the coding and categorising protocol. The content analysis was carried out by scanning keywords relative to each of the relevant variables in each of the selected reports. In order to assess the consistency and reliability of the coding process, we employed the cross-check analysis at the beginning of the process (the first documents coded by one researcher were checked independently by the second researcher and conversely, under the supervision of another member of the research team who designed the protocol). Discrepancies across coders were discussed and reconciled, involving the lead researcher of the study. Krippendorff's alpha was used to assess the inter-coder reliability of the coding process [94], in 2019 yielding values above 0.80 in all the variables tested, in a sample of $15 \%$ of all companies' reports.

For the descriptive analysis of the sample, additional information was obtained on the industry sector, number of employees, and market capitalization. These last two variables are indicators commonly used to measure the size of the organization and financial economic performance. The industry sector was obtained directly from Bolsas y Mercados Españoles (BME), the number of employees of the companies themselves and the data on market capitalization were obtained from SABI (Iberian Balance Sheet Analysis System), a database on financial information covering over 2.6 million companies in Spain and Portugal.

\section{Results}

Following the order of the proposed hypotheses, this section describes results and findings of the longitudinal analysis of SDG reporting in Spanish listed companies.

The first relevant results refer to the configuration of the sample. The sample is composed only by those Spanish listed companies that have been disclosing sustainability information through official reports in the 4 years of the period of analysis. This has led to an important reduction of the number of companies to be finally included by almost one third. It is interesting to point out that there were 13 companies that fulfilled the criteria for inclusion in 2016 but then fell out of the sample owing to their not reporting on 2017, 2018, and/or 2019. This is surprising, considering that our data suggest that the quantity 
of Non-Financial Reports by company increased over the years (104 in 2016, 105 in 2017, 118 in 2018, and 123 in 2019).

The full list of companies in the sample is included in Appendix C (Table A3). Companies were classified in accordance with the seven sectors of the BME's classification and international practice (Table 3). This study's sample is heterogeneous and consistent with the sectorial distribution of the Madrid Stock Exchange. With regard to the organization's size, companies average 26.255 employees, with a range from a minimum of 90 employees (Realia Business) to a maximum of 196.000 (Banco Santander). Market capitalization averages EURO 7549.5 million, with a range from 55.2 million (Duro Felguera) to 75,890.5 million (Inditex).

Table 3. Characteristics of the sample by sector.

\begin{tabular}{ccc}
\hline Sectors & Number & $\%$ \\
\hline Basic Mat., Industry, and Construction & 16 & $27.6 \%$ \\
Consumer Goods & 11 & $19.0 \%$ \\
Financial Services & 8 & $13.8 \%$ \\
Consumer Services & 7 & $12.1 \%$ \\
Technology and Telecommunications & 7 & $12.1 \%$ \\
Energy & 5 & $8.6 \%$ \\
Real Estate Services & 4 & $6.9 \%$ \\
Total & 58 & $100 \%$ \\
\hline
\end{tabular}

Table 4 shows the evolution of the SDG general mentions among the Spanish Listed companies from 2016 to 2019. This longitudinal analysis shows a steady increase of SDG mentions since the first year after the approval of the 2030 Agenda (2015) until 2019. Specifically, 31\% more companies mention SDGs in their reports in 2019 as opposed to 2016. In 2019, only eight companies officially reporting non-financial disclosures (and that had been reporting for the previous 3 years too) did not mention the SDGs.

Table 4. Evolution of SDG general mentions among Spanish listed companies in the period 2016-2019.

\begin{tabular}{ccccc}
\hline & $\mathbf{2 0 1 6}$ & $\mathbf{2 0 1 7}$ & $\mathbf{2 0 1 8}$ & $\mathbf{2 0 1 9}$ \\
\hline Yes & $32(55.2 \%)$ & $37(63.8 \%)$ & $44(75.9 \%)$ & $50(86.2 \%)$ \\
No & $26(44.8 \%)$ & $21(36.2 \%)$ & $14(24.1 \%)$ & $8(13.8 \%)$ \\
Total & $58(100 \%)$ & $58(100 \%)$ & $58(100 \%)$ & $58(100 \%)$ \\
\hline
\end{tabular}

Table 5 brings more detail into the previous analysis. While during the first year of SDG reporting most of the companies were simply mentioning the SDGs without reporting specific measures for each or some of them, this tendency changed from the second year onwards. Since 2017, many more companies have been reporting specific measures associated to certain SDGs than those that mention SDGs generally. This tendency seems to consolidate in 2019 , when $86 \%$ of the Spanish listed companies mentioning SDGs in their official reports also disclose specific measures. Only seven companies out of the 50 companies reporting on the SDGs fail to report specific measures. Since the approval of the 2030 Agenda, for the companies included in the sample, there has been an overall $95 \%$ increase of companies reporting specific measures for the SDGs.

Table 5. Companies mentioning SDGs in their reports and reporting specific measures on the SDGs.

\begin{tabular}{ccccc}
\hline & $\mathbf{2 0 1 6}$ & $\mathbf{2 0 1 7}$ & $\mathbf{2 0 1 8}$ & $\mathbf{2 0 1 9}$ \\
\hline Yes & $22(68.8 \%)$ & $30(81.1 \%)$ & $34(77.3 \%)$ & $43(86.0 \%)$ \\
No & $10(31.3 \%)$ & $7(18.9 \%)$ & $10(22.7 \%)$ & $7(14.0 \%)$ \\
Total & $32(100 \%)$ & $37(100 \%)$ & $44(100 \%)$ & $50(100 \%)$ \\
\hline
\end{tabular}


Table 6 focuses on whether the SDGs were mentioned in the CEO letters to stakeholders. In the initial period (2016 and 2017), the SDG mentions were infrequent (13.8\%). However, in 2018 the mentions increase up to $25.9 \%$ and the following year (2019) they increase up to $43.1 \%$. Hence, they have increased by $212 \%$ in 2019 , with almost $50 \%$ of CEOs or Presidents in our sample mentioning the SDGs in their letter to stakeholders in 2019.

Table 6. SDG mentions in the CEO/President Letter.

\begin{tabular}{ccccc}
\hline & $\mathbf{2 0 1 6}$ & $\mathbf{2 0 1 7}$ & $\mathbf{2 0 1 8}$ & $\mathbf{2 0 1 9}$ \\
\hline Yes & $8(13.8 \%)$ & $8(13.8 \%)$ & $15(25.9 \%)$ & $25(43.1 \%)$ \\
No & $50(86.2 \%)$ & $50(86.2 \%)$ & $43(74.1 \%)$ & $33(56.9 \%)$ \\
Total & $58(100 \%)$ & $58(100 \%)$ & $58(100 \%)$ & $58(100 \%)$ \\
\hline
\end{tabular}

Table 7 depicts every specific SDG as mentioned by the sample companies. The findings reveal that the four most mentioned SDGs (above 60\%) are SDG 13 (Climate Action), SDG 8 (Decent Work and Economic Growth), SDG 9 (Industry, Innovation, and Infrastructure), and SDG 4 (Quality Education). These are followed by another group of four SDGs, mentioned by more than 55\% of the companies: SDG 5 (Gender Equality), SDG 17 (Partnerships), SDG 10 (Reduced Inequalities), and SDG 12 (Responsible Production and Consumption). The less mentioned SDGs are SDG 14 (Life Below Water) and SDG 2 (Zero hunger). Despite the differences, all the SDGS are increasingly mentioned over time.

Table 7. Goals mentioned in the analyzed documents.

\begin{tabular}{|c|c|c|c|c|c|c|}
\hline & 2016 & 2017 & 2018 & 2019 & Ranking & \% Change 2016-2019 \\
\hline Goal 13. Climate Action & $25.9 \%$ & $37.9 \%$ & $50.0 \%$ & $69.0 \%$ & 1 & $166.4 \%$ \\
\hline Goal 8. Decent Work and Economic Growth & $31.0 \%$ & $43.1 \%$ & $50.0 \%$ & $67.2 \%$ & 2 & $116.8 \%$ \\
\hline Goal 9. Industry, Innovation, and Infrastructure & $32.8 \%$ & $37.9 \%$ & $48.3 \%$ & $63.8 \%$ & 3 & $94.5 \%$ \\
\hline Goal 4. Quality Education & $20.7 \%$ & $27.6 \%$ & $37.9 \%$ & $60.3 \%$ & 4 & $191.3 \%$ \\
\hline Goal 5. Gender Equality & $20.7 \%$ & $29.3 \%$ & $41.4 \%$ & $58.6 \%$ & 5 & $183.1 \%$ \\
\hline Goal 17. Partnership for the Goals & $24.1 \%$ & $32.8 \%$ & $41.4 \%$ & $58.6 \%$ & 5 & $143.2 \%$ \\
\hline Goal 10. Reduced Inequalities & $17.2 \%$ & $20.7 \%$ & $31.0 \%$ & $55.2 \%$ & 7 & $220.9 \%$ \\
\hline Goal 12. Responsible Consumption and Production & $19.0 \%$ & $27.6 \%$ & $39.7 \%$ & $55.2 \%$ & 7 & $190.5 \%$ \\
\hline Goal 7. Affordable and Clean Energy & $25.9 \%$ & $27.6 \%$ & $39.7 \%$ & $51.7 \%$ & 9 & $99.6 \%$ \\
\hline Goal 11. Sustainable Cities and Communities & $24.1 \%$ & $25.9 \%$ & $39.7 \%$ & $50.0 \%$ & 10 & $107.5 \%$ \\
\hline Goal 3. Good Health and Well-being & $20.7 \%$ & $27.6 \%$ & $36.2 \%$ & $48.3 \%$ & 11 & $133.3 \%$ \\
\hline Goal 6. Clean Water and Sanitation & $15.5 \%$ & $17.2 \%$ & $27.6 \%$ & $44.8 \%$ & 12 & $189.0 \%$ \\
\hline Goal 15. Life on Land & $15.5 \%$ & $17.2 \%$ & $20.7 \%$ & $41.4 \%$ & 13 & $167.1 \%$ \\
\hline Goal 16. Peace, Justice, and strong Institutions & $19.0 \%$ & $20.7 \%$ & $27.6 \%$ & $41.4 \%$ & 13 & $117.9 \%$ \\
\hline Goal 1. No Poverty & $19.0 \%$ & $19.0 \%$ & $20.7 \%$ & $27.6 \%$ & 15 & $45.3 \%$ \\
\hline Goal 14. Life below Water & $10.3 \%$ & $10.3 \%$ & $13.8 \%$ & $27.6 \%$ & 15 & $168.0 \%$ \\
\hline Goal 2. Zero Hunger & $8.6 \%$ & $10.3 \%$ & $13.8 \%$ & $24.1 \%$ & 17 & $180.2 \%$ \\
\hline
\end{tabular}

Table 8 presents sectorial differences in SDG reporting (considering simple mentions to the SDGs) for the period 2016-2019. First, it is noteworthy that all the companies of the sample representing the Energy sector have been reporting on SDG since 2016 except for one company that did not report on the SDGs in 2017. Second, there are four sectors with a high initial commitment to SDG mentions, which show a positive evolution over time (Basic Materials, Industry and Construction, Consumer Services, Financial Services, and Technology and Telecommunications). In 2019, 100\% of the companies of three of these sectors reported on SDG and $94 \%$ of the companies of the Basic materials, Industry, and Construction sector did the same. Finally, there is one sector (Consumer Goods) that initially had $18 \%$ of the companies reporting on the SDGs but have been raising this percentage up to $64 \%$ in 2019 . Finally, only one company (25\%) of the Real State Services sector mentions the SDGs. 
Table 8. SDG mentions by sector.

\begin{tabular}{cccccc}
\hline & $\mathbf{2 0 1 6}$ & $\mathbf{2 0 1 7}$ & $\mathbf{2 0 1 8}$ & $\mathbf{2 0 1 9}$ & Total Companies \\
\hline Energy & $100 \%$ & $80.0 \%$ & $100 \%$ & $100 \%$ & $100 \%(5)$ \\
Basic Mat., Industry, and Construction & $56.3 \%$ & $68.8 \%$ & $87.5 \%$ & $93.8 \%$ & $100 \%(16)$ \\
Consumer Goods & $18.2 \%$ & $27.3 \%$ & $45.5 \%$ & $63.6 \%$ & $100 \%(11)$ \\
Consumer Services & $71.4 \%$ & $71.4 \%$ & $100 \%$ & $100 \%$ & $100 \%(7)$ \\
Financial Services & $75.0 \%$ & $75.0 \%$ & $75.0 \%$ & $100 \%$ & $100 \%(8)$ \\
Technology and Telecommunications & $71.4 \%$ & $100 \%$ & $85.7 \%$ & $100 \%$ & $100 \%(7)$ \\
Real Estate Services & $0 \%$ & $25.0 \%$ & $25.0 \%$ & $25.0 \%$ & $100 \%(4)$ \\
Total & $55.2 \%$ & $63.8 \%$ & $75.9 \%$ & $86.2 \%$ & $100 \%(58)$ \\
\hline
\end{tabular}

Table 9 shows the relation between the Spanish listed companies' adherence to the Spanish Global Compact Network and their general mention of the SDGs. Throughout the period, the number of companies that mention the SDGs without being signatories of the UN Global Compact has been somewhat low, fluctuating between 7 and 11 (12-19\% of the sample). In contrast, both the number of signatory companies of the UN Global Compact and the proportion of them reporting on the SDGs has increased over the years. Of the 27 signatory companies of the UN Global compact in 2016, 21 (78\%) were reporting on the SDGs. In 2019, the number of signatory companies of the UN Global compact was raised to 43 , and the proportion of them mentioning the SDGs peaked to $98 \%$ (all except one). This shows an unquestionable relationship among the Spanish Listed companies between being signatory of the UN Global Compact and reporting on the SDGs.

Table 9. SDGs mention by the UN Global Compact Spanish membership.

\begin{tabular}{ccccc}
\hline \multirow{2}{*}{ Year } & \multirow{2}{*}{ SDG Reporting } & \multicolumn{3}{c}{ UN Global Compact Spanish Network Signatory } \\
\cline { 3 - 5 } & & Yes & No & Total \\
\hline \multirow{2}{*}{2016} & Yes & $21(77.8 \%)$ & $11(35.5 \%)$ & $32(55.2 \%)$ \\
& No & $6(22.2 \%)$ & $20(64.5 \%)$ & $26(44.8 \%)$ \\
& Total & $27(100 \%)$ & $31(100 \%)$ & $58(100 \%)$ \\
\hline \multirow{2}{*}{2017} & Yes & $29(80.6 \%)$ & $8(36.4 \%)$ & $37(63.8 \%)$ \\
& No & $7(19.4 \%)$ & $14(63.6 \%)$ & $21(36.2 \%)$ \\
& Total & $36(100 \%)$ & $22(100 \%)$ & $58(100 \%)$ \\
\hline \multirow{2}{*}{2018} & Yes & $37(90.2 \%)$ & $7(41.2 \%)$ & $44(75.9 \%)$ \\
& No & $4(9.8 \%)$ & $10(58.8 \%)$ & $14(24.1 \%)$ \\
& Total & $41(100 \%)$ & $17(100 \%)$ & $58(100 \%)$ \\
\hline 2019 & Yes & $42(97.7 \%)$ & $8(53.3 \%)$ & $50(86.2 \%)$ \\
& No & $1(2.3 \%)$ & $7(46.7 \%)$ & $8(13.8 \%)$ \\
& Total & $43(100 \%)$ & $15(100 \%)$ & $58(100 \%)$ \\
\hline
\end{tabular}

Table 10 shows the growing tendency among the Spanish listed companies to use both the GRI and SDG frameworks in their Non-Financial Reporting exercises. More concretely, the longitudinal analysis shows a consistently high use of the GRI standards throughout the period (always above $88 \%$ ), and a growing trend to use the two frameworks simultaneously in companies' reports. In 2016, 31 (62\%) of the 50 companies that referenced the GRI framework in their reports also mentioned the SDGs. In contrast, in 2019, 49 (90.7\%) companies out of the 54 companies that referenced the GRI framework also mentioned the SDGs. Even though in 2017 the number of companies that did not follow the GRI standards increased from 7 to 9 , the general trend seems to point towards a decrease in companies not following the GRI. In 2019, only three companies in the entire sample did not use the GRI standards. Throughout the entire period, only one company that did not follow the GRI standards has been reporting on the SDGs. 
Table 10. SDG reporting by the global reporting initiative (GRI) framework adherence.

\begin{tabular}{ccccc}
\hline \multirow{2}{*}{ Year } & \multirow{2}{*}{ SDG Reporting } & \multicolumn{3}{c}{ GRI Framework Adherence } \\
\cline { 3 - 5 } & & Yes & No & Total \\
\cline { 3 - 5 } 2016 & Yes & $31(62.0 \%)$ & $1(12.5 \%)$ & $32(55.2 \%)$ \\
& No & $19(38.0 \%)$ & $7(87.5 \%)$ & $26(44.8 \%)$ \\
& Total & $50(100 \%)$ & $8(100 \%)$ & $58(100 \%)$ \\
\hline \multirow{2}{*}{2017} & Yes & $36(75.0 \%)$ & $1(10.0 \%)$ & $37(63.8 \%)$ \\
& No & $12(25.0 \%)$ & $9(90.0 \%)$ & $21(36.2 \%)$ \\
& Total & $48(100 \%)$ & $10(100 \%)$ & $58(100 \%)$ \\
\hline \multirow{2}{*}{2018} & Yes & $43(84.3 \%)$ & $1(14.3 \%)$ & $44(75.9 \%)$ \\
& No & $8(15.7 \%)$ & $6(85.7 \%)$ & $14(24.1 \%)$ \\
& Total & $51(100 \%)$ & $7(100 \%)$ & $58(100 \%)$ \\
\hline 2019 & Yes & $49(90.7 \%)$ & $1(25.0 \%)$ & $50(86.2 \%)$ \\
& No & $5(9.3 \%)$ & $3(75.0 \%)$ & $8(13.8 \%)$ \\
& Total & $54(100 \%)$ & $4(100 \%)$ & $58(100 \%)$ \\
\hline
\end{tabular}

Table 11 shows the reporting paths taken by the Spanish listed companies with regards to the use of different types of Non-Financial Reporting. The most salient observation relates to the use of the Integrated Report. While in 2016 the vast majority of companies $(81 \%)$ were using IR as their main vehicle of Sustainability Reporting, there is a noticeable $65.9 \%$ decrease in the use of this type of report from 2016 until 2019. In 2019, only $27.9 \%$ of the companies used the IR. This raises the question of whether the sharp decrease in the use of the Integrated Report can be explained by an increase of the same magnitude in the use of another type of report.

Table 11. Type of reporting document by year.

\begin{tabular}{ccccc}
\hline Type of Reporting Document & $\mathbf{2 0 1 6}$ & $\mathbf{2 0 1 7}$ & $\mathbf{2 0 1 8}$ & $\mathbf{2 0 1 9}$ \\
\hline Integrated Report & $47(81.0 \%)$ & $51(87.9 \%)$ & $24(41.4 \%)$ & $16(27.6 \%)$ \\
Sustainability Report & & $1(1.7 \%)$ & $5(8.6 \%)$ & $9(15.5 \%)$ \\
CSR Report & $11(19.0 \%)$ & $6(10.3 \%)$ & $17(29.3 \%)$ & $5(8.6 \%)$ \\
Annual Report & & & $12(20.7 \%)$ & $17(29.0 \% \cdot)$ \\
Non-Financial Statement & & & & $11(18.9 \%)$ \\
Total & $58(100 \%)$ & $58(100 \%)$ & $58(100 \%)$ & $58(100 \%)$ \\
\hline
\end{tabular}

A deeper analysis of the trends in the use of the other types of reports does not seem to support this idea. In fact, there has been a notable dispersion in the types of reports used by companies since 2017. First, the use of Sustainability Report has been relatively small, although it has increased over the years from no reports in 2016 to nine reports in 2019. Second, the CSR Report used has not followed a linear pattern. It has moved from 11 companies in 2016, to six in 2017, almost tripling in 2018 (17 companies), and, in 2019, the number dropping again to just five companies. Third, Non-Financial Statements started to be used by 11 Spanish listed companies as the main Sustainability Reporting vehicle 1 year after the transposition of the EU Non-Financial Reporting Directive came into force in Spain (2018). Finally, the use of the Annual Report has become more prominent on the last years. After 2 years $(2016,2017)$ with none of the companies using Annual Reports to communicate sustainability issues, in 2018, 12 companies started using this type of report as their main vehicle of Sustainability Reporting, and this number increased even more the following year (2019), when 17 companies (29.3\%) used the Annual Report.

Table 12 presents the connection between the type of report and the general mention to the SDGs by year. For this purpose, the different types of Standalone Reports (CSR Report, Sustainability Report, and Non-Financial Statement) have been grouped under one single group called "Standalone Report". Hence, three different reporting options are presented in the table: Integrated Report, Standalone Report, and Annual Report. The 
table reveals that the companies more likely to report on the SDGs are, in the first place, those that adopt the Integrated Report; in the second place, those that adopt some kind of Standalone Report; in the final place, those that use Annual Reports. It is noteworthy that, given the general tendency to increase SDG reporting, all types of reports show a positive tendency as well.

Table 12. Cross-tabulation of SDG reporting, year of reporting, and type of report.

\begin{tabular}{ccccc}
\hline & $\mathbf{2 0 1 6}$ & $\mathbf{2 0 1 7}$ & $\mathbf{2 0 1 8}$ & $\mathbf{2 0 1 9}$ \\
\hline Integrated Report & $61.7 \%$ & $68.6 \%$ & $91.7 \%$ & $100.0 \%$ \\
Standalone Report & $27.3 \%$ & $28.6 \%$ & $68.2 \%$ & $84.0 \%$ \\
Annual Report & & & $58.3 \%$ & $76.5 \%$ \\
Total & $55.2 \%$ & $63.8 \%$ & $75.9 \%$ & $86.2 \%$ \\
\hline
\end{tabular}

\section{Discussion}

\subsection{General Findings}

The results of our study highlight two broad interesting findings that are relevant to better understand our hypothesis. The first is a precautionary element related to the overall low commitment of Spanish listed companies with sustainability disclosures along the period 2016-2019. Notwithstanding the growing tendency to present Non-Financial Reports and the possible positive effect of EU Directive 2014/95/EU on this trend, the proportion of companies publishing any kind of Sustainability Report is still relatively low. The findings of this paper seem to go against previous reports that Spain is a country firmly committed to Non-Financial Reporting (Sierra-Garcia et al., 2018a). This paper shows that using larger samples than previously studied, not limited to stock market selectives can lead to less optimistic views about the Non-Financial Reporting behavior of corporations in Spain.

The limited disclosure of non-financial information by Spanish listed companies points to a low commitment to sustainable development [52]. Similarly, following legitimacy theory [95], the scarce publishing of extra-financial reports might point towards a low concern of companies about their stakeholders. To understand why this may be the case, it is important to reflect on the Non-Financial Reporting policies targeted at the private sector. The longitudinal analysis of the Spanish case described in this paper encompasses both the voluntary period before the transposition of the EU Directive 2014/95/EU (2016$2017)$ and the mandatory period that came after $(2018,2019)$. Although the switch from the former period to the latter has positively influenced the number of companies that publish Non-Financial Reports, there is still a large group of companies that continue to report absolutely nothing related to sustainability (in 2019, there were still 36 companies out of 160, 22.5\%, which did not publish any kind of Non-Financial Report). Bearing in mind the need to increase all private sector efforts to fulfil the 2030 Agenda [96] and the potential of Non-Financial Reporting to act as a driver of organizational change towards sustainability [88], current reporting regulations should be revised to address the still null commitment of some companies. Thus, the debate on voluntary vs. mandatory NonFinancial Reporting [97] should be placed at the centre of future research. The cross-country analysis between EU members subject to the EU Directive 2014/95/EU would cast light into this debate.

The second key finding of this longitudinal analysis relates to the general trend observed among Spanish listed companies to change the type of reports used to disclose sustainability issues over time. Surprisingly, the number of companies that use IR has been decreasing over the years. At the same time, the use of Annual Reports as the main vessel for the disclosure of non-financial information has grown significantly within the last two years. These findings reveal an interesting shift which coincides with the entry into force of the EU Directive 2014/95/EU in Spain. A possible reason behind this shift could be that the new mandate to present a Non-Financial Statement led companies to restrict their reporting efforts to the strictly legal, leaving aside the Non-Financial Reporting efforts that until 
then they published voluntarily. Hence, companies would be either moving towards a full integration of their non-financial disclosures into their Annual Reports just as they did with the Annual Corporate Governance Report when it became mandatory [98]; or reducing their Non-Financial Reporting efforts by replacing the previous Integrated Reports or standalone reports with a less ambitious (mandatory) Non-Financial Statement, aimed at complying with the new legal requirements. Resolving whether reality fits any of these hypotheses is beyond the scope of this study. However, these findings open a potential avenue for future qualitative research about the use of different types of Non-Financial Reports over time. Research should aim to consider both the quality of the information presented in each type of report and the motivations behind the changes. Additionally, it may be of interest to study the effects of EU Directive 2014/95/EU on the shift from one type of report to another.

\subsection{Validating the Study's Hypothesis}

The research results confirm the first hypothesis of this article, namely that SDG reporting among Spanish listed companies has increased in quantity since the first year after the approval of the 2030 Agenda. General mentions of the SDGs have increased by $31 \%$ since the approval of the Agenda (from 2016 to 2019) and the latest data available shows that more than $80 \%$ of the companies were mentioning the SDGs in their reports in 2019. More importantly, disclosures of measures associated to specific SDGs have increased notably since 2016. The same occurs with SDG mentions in CEO letters to stakeholders. The fact that the tendency observed is relatively steady seems to point at an organic growth of the companies' awareness about the 2030 Agenda. Our findings on SDG reporting are consistent with the latest international findings on the topic, which identify a growing tendency among corporations around the world to acknowledge the SDGs, prioritize them, and present some evidence of alignment and contribution [29,51,99]. As seen above, the transposition of Directive 2014/95/EU into Spanish law in 2018 may have positively affected the number of publications of Non-Financial Reports by Spanish listed companies in 2018 and 2019. However, our analysis does not allow us to infer any direct correlation between the transposition of the directive and an increase in SDG Reporting. Perhaps, following similar studies [79], other research efforts could assess whether the transposition of EU Non-Financial Reporting Directive into Spanish Law (2018) had a significant effect on the quality and quantity of SDG reporting by Spanish listed companies.

The results found regarding the SDGs most mentioned by Spanish listed companies (SDG 13, SDG 8, SDG 9) and the ones least mentioned by businesses (SDG 2) coincide with similar studies conducted in the area of reporting on the Agenda 2030 [10,27]. It would be key to establish what these results mean. Izzo et al. [89] inferred from the outcomes of their study that most companies considered the most cited SDGs as the ones that could help them respond strategically to the most immediate challenges they were facing. Conclusions or inferences about the motives behind the reporting of companies on specific SDGs are beyond the scope of the quantitative analysis of this paper. Yet, one could argue that the true drivers behind reporting on specific SDGs are legal requirements (e.g., reporting on greenhouse gas emissions) or conditions corporations must fulfil to conserve their competitive advantage in the long term. If this was the case, specific mentions of SDGs would be far from departing from these companies' materiality assessments, but rather would be more oriented to 'cherry-picking' [100] those SDGs most obviously linked to each business' activity. Hence, further qualitative research should aim to uncover the relationship between SDG prioritisation and the motives behind such process [100].

Sectorial differences have also been identified in this study with regards to SDG reporting. Surprisingly, they are different from the ones found by Izzo et al. [27] who analysed a sample of Italian listed companies. Whereas these authors concluded that operating in a specific sector does not significantly affect a company's decision to disclose SDG information, our analysis seems to indicate the contrary. A longitudinal analysis of the SDG reporting of Spanish listed companies throughout four years clearly shows that 
there are sectors more likely to report on the SDGs than others. Previous studies have proven the relationship between environmentally sensitive sectors and higher performance in Non-Financial Reporting [101]. This would partially explain our findings. However, further research should fully establish the causes of why certain sectors perform better (e.g., technology) than others (e.g., building and construction). Using cross-country analysis involving a large sample of companies would help draw sound conclusions on this topic.

Our study also confirms our second hypothesis, which explored a potential positive relationship between being a signatory of the UN Global Compact and reporting on the SDGs. The results confirm Van Der Waal's conclusions [71], and are consistent with Fonseca and Carvalho [74], who recently established that communication on the SDGs is more prominent among Portuguese Quality, Environmental, and Occupational Health and Safety (QEOHS)-certified management systems organizations that are members of the United Nations Global Compact Network Portugal. This paper's results are also consistent with the latest Communication of Progress of the Spanish Global Compact Network [102], which concluded that $77 \%$ of large companies who are members of the Network express their commitment to the SDGs in their Sustainability Reports. Despite these results, it is important to highlight the limited explanatory capacity the variable on Global Compact membership has by itself. Specifically, it seems redundant that companies that decide to become members or signatories of such organization also express their commitment with this organization's tenets (i.e., the SDGs). Thus, the authors encourage future research on this topic to look beyond companies' explicit commitment to the SDGs and assesses other variables that may better explain a company's commitment to sustainable development and Corporate Sustainability, such as the quality of SDG reporting.

The results of this study also confirm our third hypothesis, namely that Spanish listed companies that adopt the GRI standards are more likely to report on the SDGs than companies that do not. The wide use of the GRI standards among sampled companies corroborates the conclusions reached by previous studies regarding the preponderance of the GRI as the most widely used Non-Financial Reporting framework among corporations [63]. Simultaneously, the growing convergence between the GRI framework and UN Global Compact membership might be interpreted as the result of the partnership initiated by the the GRI and the UN through the joint publication of guidelines in 2017 [75]. Beyond proving the positive relationship between these two frameworks, Szennay [103] used cluster analysis to show the specific links between the SDGs and GRI indicators. Furthermore, Ordoñez [103] analysed the car industry and found that GRI 300 can be a useful measurement tool to operationalise the SDGs. Following these authors, future research should aim to identify specific ways in which this connection between frameworks can support the achievement of the 2030 Agenda.

Finally, the relationship between the general findings regarding the type of report published by companies (detailed in the previous subsection), and SDG reporting should be defined. Our study confirms that a link can be established between the choice of certain types of Non-Financial Reports by companies and the willingness of businesses to report on the SDGs. More specifically, this longitudinal analysis has shown that those companies using Integrated Reports to disclose sustainability information are most likely to report on the SDGs. These are followed by businesses publishing standalone reports. Finally, companies that present their non-financial information in Annual Reports are the least likely to report on the SDGs. Since, as this paper asserts, the SDG reporting trend is on the rise, all types of reports tend to mention more the Goals with every passing year. Nevertheless, it is important to underline that those reports in which the connection to the SDGs is strongest (Integrated Reports) are becoming less popular than those whose connection to the 2030 Agenda is weakest (Annual Reports). As mentioned above, this might be the result of a change in business priorities or even on how reports are named owing to the transposition of EU Directive 2014/95/EU into Spanish law. Yet, careful attention should be paid in future studies to assess the potential negative effect that could result from making Non-Financial Reporting a legal requirement. 


\section{Conclusions}

This paper portrays a longitudinal analysis of the SDG reporting practices of Spanish listed companies from the approval of the 2030 Agenda until 2020. To the best of our knowledge, this is the first research effort to monitor SDG reporting over a period of years in an EU member state since the approval of the 2030 Agenda. While the research takes a rather descriptive perspective to approach the performance on SDG reporting of Spanish listed companies, it does so in an attempt to test some of the latest hypotheses in the nascent academic field of SDG reporting. Our results support the idea that the growing notoriety of the 2030 Agenda in recent years has led to a greater commitment by companies, in this case Spanish listed companies, to the SDGs. Our research also proves that the connection between companies and international standard-setting organisations sponsoring the Agenda (Global Compact, GRI) has a positive effect on SDG reporting.

The 2030 Agenda builds on the most widely accepted notion of sustainable development to present a set of shared goals to which both the public and private sectors must commit to reverse the harm humans have done to the Earth's ecosystems. From a management science perspective, it is of utmost importance to further define this link by developing the connection between the academic field of Corporate Sustainability and the actionable notion of sustainable development. By collecting and analysing data describing the commitment of businesses to the 2030 Agenda, this article contributes to a better understanding of the relationship between accountability and Non-Financial Reporting, as a stream of Corporate Sustainability, through the latest data on SDG reporting by Spanish listed companies. This connection is materialised in concrete aspects such as the contribution of businesses to the reduction of greenhouse gas emissions, the reduction of gender inequalities, the implementation of policies against corruption and bribery, the respect of human rights or supplier control policies, and others. SDG reporting can be seen as a repository where business actions in the social, environmental, and economic fields are compiled, together with information on internal and external governance topics such as the contribution to social justice or the alliances that a company builds to contribute to sustainable development. Approaching this rich spectrum of disclosed information from an academic perspective can help better understand the inherent tensions within the notion of sustainable development, thus contributing in equal parts to updating current academic knowledge and improving the basis on which future legislation on Non-Financial Reporting is built.

The results of this study show an ambivalent reality. On the one hand, about half of Spanish listed companies do not seem to invest in sustainability reporting or on responding to increasing stakeholder interest or demands through non-financial disclosure. Many Spanish listed companies are still far from endorsing stakeholder capitalism, an economic model that does not prioritise the maximisation of profit for shareholders but value to society as a whole. On the other hand, half of Spanish listed companies have been presenting Non-Financial Reports from 2016 and have made significant progress on SDG reporting. Among these companies, SDG generic mentions and descriptions of the measures associated to the Goals in reports have increased over the period studied. Furthermore, their president or CEOs have been increasingly mentioning the SDGs in their letters to stakeholders. This might be a sign of strong commitment by some of Spain's top managers to the 2030 Agenda, or at least of a better understanding of stakeholder demands. It has also been noted that those companies using standards such as the GRI or that are signatories of the UN Global Compact are more likely to report on the SDGs than those that are not. Similarly, companies publishing Integrated Reports or standalone reports for their sustainability Reporting are more likely to report on the SDGs than those publishing only Annual Reports.

With regard to report typology, the authors came across an unexpected fact: The downward trend in the use of Integrated Reports as the main communication tool on sustainability by Spanish listed companies. The transposition of EU Directive 2014/95/EU in Spain in 2018 has been identified as a potential cause for this shift. Although it is beyond 
the scope of this analysis to investigate how this shift happened, this article suggests that future research should explore the relationship between SDG reporting and the types of reports adopted by companies, in line with recent studies of the same kind $[27,28]$.

These results might also have implications for policy consideration. Specifically, it would be key to consider how the introduction of EU Directive 2014/95/EU, by mandating non-financial disclosure, may have had an effect opposite to encouraging large companies to develop a responsible approach to business. The relative flexibility on 'how' to report and the lax assurance measures required might have created a loophole for under-reporting. Moreover, in the Spanish case, the absence of fines associated to not reporting might have been seen by some as a (soft) statement of intent of the Government's agenda for Corporate Sustainability. This could explain the lack of reporting of those companies that still have to embark on non-financial disclosure. For those companies that were already committed to voluntary Non-Financial Reporting, it could also be the case that the legal obligation to report lowered their levels of demand.

All these considerations point at nuanced ways of approaching the voluntary vs. mandatory debate in the Non-Financial Reporting academic field [58]. They raise several questions that could be approached in future research: Should regulatory powers establish incentives (carrots) to bring on board those companies that, even having the obligation to report, still fail do so? Or else should they establish fines (sticks) to guarantee their production of non-financial reports? Is there any point in making non-financial disclosures if the company is not motivated to do so? These questions could be approached through qualitative interviews and/or a new analysis of relevant non-financial reports that complements our own.

By adopting these data-collection and data-analysis methods, future research efforts could avoid some of the limitations that come with a longitudinal perspective such as the one described in this article. First, an approach such as this one impacts the size of the sample of analysis. While it is a sound methodology to evaluate progression over time, it does limit the generalisability of results, especially when it comes to finding sectorial differences. Second, the focus on macro-tendencies related to SDG reporting limits the ability to provide in-depth analysis about the quality of the companies' disclosures with regards to each SDG separately. Even though three variables have been used to approach SDG reporting (General Mentions, Specific Mentions, and the CEO letter), their explanatory capacity is limited as compared to other analysis models such as the SDG Reporting Score [69]. Further research should aim to combine the longitudinal analysis we defined with more refined qualitative proxies representing a firm's orientation toward SDG reporting (such as in-depth interviews with C-level managers). Finally, while this research offers a clear descriptive picture SDG reporting by Spanish listed companies over time, the organisational and institutional determinants of such reporting were deemed to be beyond the scope of the study $[67,69]$. Future research could aim to tackle these from a longitudinal perspective.

The authors of this article encourage further research that not only validates the results obtained here, but also raises new questions on policy design and the business contribution to the 2030 Agenda. The SDGs, provide a concise and attractive mechanism that can help promote reporting among undecided companies, aligning them with long-term global policy. While it is true that focusing strictly on mentions of the SDGs may be considered a too general language to be applied in business management, it is probably this type of language that allows the establishment of communication bridges between different social agents, thus facilitating the construction of multi-stakeholder projects, or sometimes even partnerships, for sustainable development (SDG 17). In the current context of the Covid-19 pandemic, the value of bridges for communication between multiple entities across the globe should not be underestimated. This pandemic has highlighted the extreme fragility of the economic system in which businesses operate and has demonstrated the unquestionable need to build multi-lateral alliances to overcome the health and economic crisis. To build these alliances, it is essential that the public sector be able to design solid 
policies that encourage business participation and co-responsibility in the achievement of the SDGs. Thus, business performance regarding the 2030 Agenda should be monitored closely not only by reporting institutions, but also by academics as stakeholders of the business sphere. From this perspective, connections between SDG reporting, strategic management and sustainability performance should be analysed by future research. Failure to do so will lead to future ineffective policy based on a lack of relevant evidence and, thus, difficulties to improve the goals and targets of the next global sustainability policy endorsed by the EU and other international organizations.

The study's relevance rests on it being a milestone to understand how the 2030 Agenda has been implemented year by year since its adoption in 2015 by a representative group of companies in an EU member state. The aforementioned results and conclusions can be used to identify differences between the nature of the contribution of large companies to the SDGs and the contribution of other players in the global arena. The information that has been presented has great value to help build future evidence-based accountancy and accountability policies at Spanish and European levels; policy that can greatly contribute to furthering the contribution of large companies to sustainable development. Management researchers interested in Corporate Sustainability should focus on furthering studying the accountability parameters and criteria that will most likely influence business reporting as global actors contribute to the SDGs. This study defines some of these concepts and their role in shaping the current map of international corporate reporting.

Author Contributions: Conceptualization, methodology, investigation, writing-review and editing, F.C.-P., E.O.-R., M.C.-D., and E.J.-L.; writing-original draft preparation, F.C.-P.; methodology, F.C.-P., E.O.-R., M.C.-D., and E.J.-L.; formal analysis, F.C.-P., E.O.-R., and M.C.-D. All authors have read and agreed to the published version of the manuscript.

Funding: This research has received partial funding from La Caixa Foundation, grant number 201901.

Institutional Review Board Statement: Not applicable.

Informed Consent Statement: Not applicable.

Data Availability Statement: The data presented in this study are available on request from the corresponding author.

Acknowledgments: The authors would like to thank Liliana Arroyo, Àngel Castiñeira, Anna Maria Gonzalez, Isa Nadal, Alba Rovira, and Àngel Pes for their support during different phases of this research effort.

Conflicts of Interest: The authors declare no conflict of interest. The funders had no role in the design of the study; in the collection, analyses, or interpretation of data; in the writing of the manuscript, or in the decision to publish the results.

\section{Appendix A}

Table A1. Reporting typologies of the listed companies, 2016-2019.

\begin{tabular}{cccccc}
\hline Reporting Typology & $\mathbf{2 0 1 6}$ & $\mathbf{2 0 1 7}$ & $\mathbf{2 0 1 8}$ & $\mathbf{2 0 1 9}$ & Frequency \\
\hline 1 & IR & IR & IR & IR & 11 \\
2 & IR & IR & AR & AR & 7 \\
3 & IR & IR & IR & SR & 5 \\
4 & IR & IR & CSR & NFS & 3 \\
5 & IR & IR & AR & NFS & 3 \\
6 & IR & IR & CSR & CSR & 3 \\
\hline
\end{tabular}


Table A1. Cont.

\begin{tabular}{|c|c|c|c|c|c|}
\hline Reporting Typology & 2016 & 2017 & 2018 & 2019 & Frequency \\
\hline 8 & IR & IR & IR & SR & 2 \\
\hline 9 & IR & IR & CSR & IR & 2 \\
\hline 10 & IR & IR & CSR & SR & 2 \\
\hline 11 & IR & IR & CSR & $\mathrm{AR}$ & 2 \\
\hline 12 & CSR & IR & IR & IR & 2 \\
\hline 13 & CSR & CSR & CSR & NFS & 2 \\
\hline 14 & IR & IR & IR & NFS & 1 \\
\hline 15 & IR & IR & CSR & CSR & 1 \\
\hline 16 & CSR & IR & CSR & IR & 1 \\
\hline 17 & CSR & IR & CSR & CSR & 1 \\
\hline 18 & CSR & SR & IR & NFS & 1 \\
\hline 19 & CSR & CSR & $\mathrm{AR}$ & NFS & 1 \\
\hline Total & & & & & 58 \\
\hline
\end{tabular}

IR: Integrated report; SR: Sustainability report; CSR: CSR report; AR: Annual report; NFS: Non-financial Statement. Source: Own elaboration and SABI database (market capitalization).

\section{Appendix B}

Table A2. Codebook.

\begin{tabular}{|c|c|c|}
\hline Variable Name & Description & Codes \\
\hline SDG mention & $\begin{array}{c}\text { Explicit reference to the SDGs in the } \\
\text { report }\end{array}$ & $\begin{array}{l}\text { When the reporting document mentions the } \\
\text { SGDs, it is encoded as } 1 \text { 'Yes' ( } 0 \text { ' } \mathrm{No}^{\prime} \text {, otherwise). }\end{array}$ \\
\hline $\begin{array}{l}\text { SDG mention President/CEO } \\
\text { Letter }\end{array}$ & $\begin{array}{l}\text { Explicit reference to the SDGs in the } \\
\text { Letter of President or the Letter to } \\
\text { Stakeholders }\end{array}$ & $\begin{array}{l}\text { When the Letter of President or the Letter to } \\
\text { Stakeholders mention the SGDs, it is encoded as } \\
1 \text { 'Yes' (0 'No', otherwise). }\end{array}$ \\
\hline SDG Goals & $\begin{array}{l}\text { Explicit reference to specific measures } \\
\text { related to the SDGs in the report }\end{array}$ & $\begin{array}{l}\text { When the reporting document discloses in detail } \\
\text { specific measures or actions on each SDG, it is } \\
\text { encoded as } 1 \text { 'Yes' ( } 0 \text { 'No', otherwise). }\end{array}$ \\
\hline GRI standard & $\begin{array}{l}\text { Application of the GRI standard to } \\
\text { disclose non-financial information }\end{array}$ & $\begin{array}{l}\text { When the reporting document refers to the } \\
\text { application of the GRI standard for disclosing } \\
\text { non-financial information, it is encoded as } 1 \text { 'Yes' } \\
\text { ( } 0 \text { ' } \mathrm{No}^{\prime} \text {, otherwise). }\end{array}$ \\
\hline UN Global Compact & UN Global Compact membership & $\begin{array}{l}\text { When the reporting document makes any } \\
\text { reference to the participation of the company in } \\
\text { the UN Global Compact, it is encoded as } 1 \text { 'Yes' } \\
\left.\text { ( } 0 \text { ' } \mathrm{No}^{\prime} \text { ', otherwise }\right) \text {. }\end{array}$ \\
\hline
\end{tabular}

\section{Appendix C}

Table A3. Companies analysed.

\begin{tabular}{ccccc}
\hline Order & Name & Sector & $\begin{array}{c}\text { Employees } \\
\text { Year 2019 }\end{array}$ & $\begin{array}{c}\text { Market Capitalization } \\
\text { m EUR (Last avail. Yr.) }\end{array}$ \\
\hline 1 & ACCIONA & Basic Mat., Ind., and Const. & 11.330 & 4231.48 \\
2 & ACERINOX & Basic Mat., Ind., and Const. & 5.977 & 2391.30 \\
3 & ACS & Basic Mat., Ind., and Const. & 190.431 & $10,645.10$ \\
4 & AENA & Consumer Services & 8.878 & $20,362.50$ \\
5 & ALMIRALL & Consumer Goods & 1.765 & 2324.42 \\
\hline
\end{tabular}


Table A3. Cont.

\begin{tabular}{|c|c|c|c|c|}
\hline Order & Name & Sector & $\begin{array}{l}\text { Employees } \\
\text { Year } 2019\end{array}$ & $\begin{array}{l}\text { Market Capitalization } \\
\text { m EUR (Last avail. Yr.) }\end{array}$ \\
\hline 6 & AMADEUS IT Group & Tech. and Telecom. & 19.442 & $26,697.96$ \\
\hline 7 & APPLUS Services & Basic Mat., Ind., and Const. & 23.051 & 1385.85 \\
\hline 8 & ATRESMEDIA & Consumer Services & 2.527 & 984.65 \\
\hline 9 & BBVA & Financial Services & 25.912 & n.a. \\
\hline 10 & BANCO DE SABADELL & Financial Services & 24.454 & n.a. \\
\hline 11 & BANCO SANTANDER & Financial Services & 196.000 & n.a. \\
\hline 12 & BANKIA & Financial Services & 15.609 & n.a. \\
\hline 13 & BANKINTER & Financial Services & n.a. & n.a. \\
\hline 14 & Bolsas y Mercados Españoles & Financial Services & 796 & 2633.89 \\
\hline 15 & BORGES & Consumer Goods & 493 & 120.33 \\
\hline 16 & CAIXABANK & Financial Services & 35.736 & $18,925.27$ \\
\hline 17 & CELLNEX TELECOM & Tech. and Telecom. & 1.605 & 5187.39 \\
\hline 18 & Cementos Molins & Basic Mat., Ind., and Const. & 4.932 & 1110.74 \\
\hline 19 & CIE Automotive & Basic Mat., Ind., and Const. & 28.124 & 2765.76 \\
\hline 20 & CODERE & Consumer Services & 12.529 & 385.25 \\
\hline 21 & CAF & Basic Mat., Ind., and Const. & 13.179 & 1240.96 \\
\hline 22 & DIA & Consumer Goods & 39.379 & 287.26 \\
\hline 23 & Duro Felguera & Basic Mat., Ind., and Const. & 1.321 & 55.20 \\
\hline 24 & EBRO FOODS & Consumer Goods & 6.117 & 2749.30 \\
\hline 25 & ELECNOR & Basic Mat., Ind., and Const. & 14.855 & 1148.40 \\
\hline 26 & ENAGAS & Energy & 1.306 & 5636.52 \\
\hline 27 & ENCE & Consumer Goods & 1.131 & 1350.80 \\
\hline 28 & ENDESA & Energy & 9.952 & $21,312.68$ \\
\hline 29 & ERCROS & Basic Mat., Ind., and Const. & 1.297 & 335.93 \\
\hline 30 & EUSKALTEL & Tech. and Telecom. & 586 & 1248.73 \\
\hline 31 & FAES FARMA & Consumer Goods & 1.440 & 802.18 \\
\hline 32 & FERROVIAL & Basic Mat., Ind., and Const. & 89.968 & $13,250.47$ \\
\hline 33 & FLUIDRA & Basic Mat., Ind., and Const. & 5.357 & 1915.21 \\
\hline 34 & FCC & Basic Mat., Ind., and Const. & n.a. & 4432.26 \\
\hline 35 & GESTAMP Automoción & Basic Mat., Ind., and Const. & 43.882 & 2860.31 \\
\hline 36 & GLOBAL DOMINION ACCESS & Tech. and Telecom. & 9.630 & 728.84 \\
\hline 37 & GRIFOLS & Consumer Goods & 24.003 & 9758.37 \\
\hline 38 & Grupo EZENTIS & Tech. and Telecom. & 12.455 & 157.47 \\
\hline 39 & IBERDROLA & Energy & 35.374 & $44,898.56$ \\
\hline 40 & IBERPAPEL GESTION & Consumer Goods & 294 & 364.31 \\
\hline 41 & INDRA SISTEMAS & Tech. and Telecom. & 49.607 & 1454.75 \\
\hline 42 & INDITEX & Consumer Goods & 176.611 & $75,890.48$ \\
\hline 43 & Inmobiliaria COLONIAL & Real Estate Services & 234 & 4133.51 \\
\hline 44 & Laboratorios Farmacéuticos ROVI & Consumer Goods & 1.310 & 978.40 \\
\hline 45 & MAPFRE & Financial Services & 34.324 & 7144.56 \\
\hline 46 & MEDIASET España & Consumer Services & 1.559 & 1797.62 \\
\hline 47 & $\begin{array}{l}\text { MELIA HOTELS } \\
\text { INTERNATIONAL }\end{array}$ & Consumer Services & 45.717 & 1885.84 \\
\hline 48 & MERLIN PROPERTIES & Real Estate Services & 218 & 5308.41 \\
\hline 49 & NATURGY Energy Group & Energy & 11.847 & $22,275.34$ \\
\hline 50 & NEINOR HOMES & Real Estate Services & 273 & 1027.07 \\
\hline 51 & NH HOTEL GROUP & Consumer Services & 13.105 & 1590.68 \\
\hline 52 & OHL & Basic Mat., Ind., and Const. & 18.782 & 186.83 \\
\hline 53 & PHARMA MAR & Consumer Goods & 487 & 242.69 \\
\hline 54 & PRISA & Consumer Services & 8.951 & 982.64 \\
\hline 55 & REALIA BUSINESS & Real Estate Services & 90 & 586.78 \\
\hline 56 & REPSOL & Energy & 25.228 & $22,474.13$ \\
\hline 57 & SACYR & Basic Mat., Ind., and Const. & 43.466 & 965.40 \\
\hline 58 & TELEFONICA & Tech. and Telecom. & 117.347 & $38,105.06$ \\
\hline
\end{tabular}




\section{References}

1. United Nations General Assembly. Transforming Our World: The 2030 Agenda for Sustainable Development; United Nations General Assembly: New York, NY, USA, 2015; p. 35.

2. Van Zanten, V.T. Multinational enterprises and the Sustainable Development Goals: An institutional approach to corporate engagement. J. Int. Bus. Policy 2018, 1, 208-233. [CrossRef]

3. Biermann, F.; Kanie, N.; Kim, R.E. Global governance by goal-setting: The novel approach of the UN Sustainable Development Goals. Curr. Opin. Environ. Sustain. 2017, 26-27, 26-31. [CrossRef]

4. Scheyvens, R.; Banks, G.; Hughes, E. The Private Sector and the SDGs: The Need to Move Beyond 'Business as Usual. Sustain. Dev. 2016, 24, 371-382. [CrossRef]

5. Deloitte. 2030 Purpose: Good Business and a Better Future. Connecting Sustainable Development with Enduring Commercial Success; Deloitte: London, UK, 2017.

6. Business \& Sustainable Development Comission. Better Business, Better World; Business \& Sustainable Development Comission: London, UK, 2017.

7. DNV-GL. Global Opportunity Report. Your Guide to a World of Opportunities; DNV-GL: Oslo, Norway, 2017.

8. UNCTAD; UN Global Compact; UNEPFI; PRI. Private Sector Investment and Sustainable Development. The Current and Potential Role of Institutional Investors, Companies, Banks and Foundations in Sustainable Development; UN Global Compact: New York, NY, USA, 2015.

9. Blowfield, M. Business and development: Making sense of business as a development agent. Corp. Gov. Int. J. Bus. Soc. 2012, 12, 414-426. [CrossRef]

10. PWC. Make it Your Business: Engaging with the Sustainable Development Goals; PWC: London, UK, 2016.

11. Scott, L.; McGill, A. From Promise to Reality: Does Business Really Care about the SDGs? And what Needs to Happen to Turn Words into Action; PWC: London, UK, 2018.

12. Van Houten, F.; McDermott, B. The Compact for Responsive and Responsible Leadership; World Economic Forum: Colony, Switzerland, 2017; Volume 41, pp. 2016-2017.

13. UN Global Compact. Blueprint for Business Leadership on the SDGs; UN Global Compact: New York, NY, USA, 2017.

14. World Business Council for Sustainable Development. CEO Guide to the SDGs; World Business Council for Sustainable Development: Geneva, Switzerland, 2017.

15. GRI; UN Global Compact; WBCSD. SDG Compass: The Guide for Business Action on the SDGs; UN Global Compact: New York, NY, USA, 2016.

16. KPMG. How to Report on the SDGs; KPMG: Amstelveen, The Netherlands, 2018; p. 33.

17. Rosati, F.; Faria, L.G.D. Addressing the SDGs in sustainability reports: The relationship with institutional factors. J. Clean. Prod. 2019, 215, 1312-1326. [CrossRef]

18. Geissdoerfer, M.; Morioka, S.N.; de Carvalho, M.M.; Evans, S. Business models and supply chains for the circular economy. J. Clean. Prod. 2018, 190, 712-721. [CrossRef]

19. Donoher, W.J. The multinational and the legitimation of sustainable development. Transnatl. Corp. 2017, 24, 49-60. [CrossRef]

20. Topple, C.; Donovan, J.D.; Masli, E.K.; Borgert, T. Corporate sustainability assessments: MNE engagement with sustainable development and the SDGs. Transnatl. Corp. 2017, 24, 61-71. [CrossRef]

21. Hahn, T.; Figge, F.; Pinkse, J.; Preuss, L. A Paradox Perspective on Corporate Sustainability: Descriptive, Instrumental, and Normative Aspects. J. Bus. Ethics 2018, 148, 235-248. [CrossRef]

22. De Neve, J.E.; Sachs, J.D. The SDGs and human well-being: A global analysis of synergies, trade-offs, and regional differences. Sci. Rep. Nat. Res. 2020, 10, 1-12. [CrossRef]

23. Tsalis, T.A.; Malamateniou, K.E.; Koulouriotis, D.; Nikolaou, I.E. New challenges for corporate sustainability reporting: United Nations' 2030 Agenda for sustainable development and the sustainable development goals. Corp. Soc. Responsib. Environ. Manag. 2020, 27, 1617-1629. [CrossRef]

24. Bebbington, J.; Unerman, J. Achieving the United Nations Sustainable Development Goals: An enabling role for accounting research. Account. Audit. Account. J. 2018, 31, 2-24. [CrossRef]

25. Sierra-Garcia, L.; Garcia-Benau, M.; Bollas-Araya, H. Empirical Analysis of Non-Financial Reporting by Spanish Companies. Adm. Sci. 2018, 8, 29. [CrossRef]

26. Tarquinio, L.; Raucci, D.; Benedetti, R. An Investigation of Global Reporting Initiative Performance Indicators in Corporate Sustainability Reports: Greek, Italian and Spanish Evidence. Sustainability 2018, 10, 897. [CrossRef]

27. Izzo, M.F.; Ciaburri, M.; Tiscini, R. The challenge of sustainable development goal reporting: The first evidence from italian listed companies. Sustainability 2020, 12, 3494. [CrossRef]

28. Yu, S.; Sial, M.S.; Tran, D.K.; Badulescu, A.; Thu, P.A.; Sehleanu, M. Adoption and implementation of sustainable development goals (SDGs) in China-Agenda 2030. Sustainability 2020, 12, 6288. [CrossRef]

29. Steffen, W.; Broadgate, W.; Deutsch, L.; Gaffney, O.; Ludwig, C. The trajectory of the anthropocene: The great acceleration. Anthr. Rev. 2015, 2, 81-98. [CrossRef]

30. Steffen, W.; Richardson, K.; Rockström, J.; Cornell, S.E.; Fetzer, I.; Bennett, E.M.; Biggs, R.; Carpenter, S.R.; De Vries, W.; De Wit, C.A.; et al. Planetary boundaries: Guiding human development on a changing planet. Science 2015, 347. [CrossRef]

31. Meadows, D.H.; Meadows, D. The history and conclusions of The Limits to Growth. Syst. Dyn. Rev. 2007, 23, 191-197. [CrossRef] 
32. Ripple, W.J.; Wolf, C.; Newsome, T.M.; Barnard, P.; Moomaw, W.R. Corrigendum: World Scientists' Warning of a Climate Emergency. Bioscience 2020, 70, 8-12. [CrossRef]

33. United Nations General Assembly. Report of the World Commission on Environment and Development: Our Common Future; United Nations General Assembly: New York, NY, USA, 1987.

34. Green, D. From Poverty to Power: How Active Citizens and Effective States Can Change the World; Oxfam-Practical Action Publishing: Warwickshire, UK, 2012; ISBN 9781853397400.

35. Crane, A. From governance to Governance: On Blurring Boundaries. J. Bus. Ethics 2010, 94, 17-19. [CrossRef]

36. Rüdiger, H. Integrating corporate responsibility and sustainable development: A normative-conceptual approach to holistic management thinking. J. Glob. Responsib. 2011, 2, 8-22. [CrossRef]

37. Haddock-Fraser, J.E.; Tourelle, M. Corporate motivations for environmental sustainable development: Exploring the role of consumers in stakeholder engagement. Bus. Strategy Environ. 2010, 19, 527-542. [CrossRef]

38. Ruiz, S.; Romero, S.; Fernandez-Feijoo, B. Stakeholder engagement is evolving: Do investors play a main role? Bus. Strategy Environ. 2020. [CrossRef]

39. Kolcava, D.; Rudolph, L.; Bernauer, T. Voluntary business initiatives can reduce public pressure for regulating firm behaviour abroad. J. Eur. Public Policy 2020, 1-24. [CrossRef]

40. Kolk, A. The social responsibility of international business: From ethics and the environment to CSR and sustainable development. J. World Bus. 2016, 51, 23-34. [CrossRef]

41. Schwartz, M.S.; Carroll, A.B. Integrating and Unifying Competing and Complementary Frameworks: The Search for a Common Core in the Business and Society Field. Bus. Soc. 2007, 47, 148-186. [CrossRef]

42. Slawinski, N.; Bansal, P. Short on Time: Intertemporal Tensions in Business Sustainability. Organ. Sci. 2015, 26, 531-549. [CrossRef]

43. Dyllick, T.; Hockerts, K. Beyond the business case for corporate sustainability. Bus. Strategy Environ. 2002, 11, 130-141. [CrossRef]

44. Ordonez-Ponce, E.; Khare, A. GRI 300 as a measurement tool for the United Nations sustainable development goals: Assessing the impact of car makers on sustainability. J. Environ. Plan. Manag. 2021, 64, 47-75. [CrossRef]

45. Elkington, J. Partnerships from cannibals with forks: The triple bottom line of 21st-century business. Environ. Qual. Manag. 1998. [CrossRef]

46. Janetschek, H.; Brandi, C.; Dzebo, A.; Hackmann, B. The 2030 Agenda and the Paris Agreement: Voluntary contributions towards thematic policy coherence. Clim. Policy 2020, 20, 430-442. [CrossRef]

47. Business Roundtable. Available online: https:/ /www.businessroundtable.org/ (accessed on 20 March 2020).

48. Schwab, K. Davos Manifesto 1973: A Code of Ethics for Business Leaders; World Economic Forum: Colony, Switzerland, 2019.

49. Fink, L. A Fundamental Reshaping of Finance. Available online: https://www.blackrock.com/corporate/investor-relations/ larry-fink-ceo-letter (accessed on 10 March 2020).

50. Buchholz, R.A.; Rosenthal, S.B. Toward a Contemporary Conceptual Framework for Stakeholder Theory. J. Bus. Ethics 2005, 58, 137-148. [CrossRef]

51. WBCSD. Reporting Matters 2019; WBCSD: Geneva, Switzerland, 2019; pp. 1-60.

52. Lozano, R.; Huisingh, D. Inter-linking issues and dimensions in sustainability reporting. J. Clean. Prod. 2011, 19, 99-107. [CrossRef]

53. GRI. Gri 101: Foundation; GRI: Amsterdam, The Netherlands, 2016.

54. Fifka, M. The development and state of research on social and environmental reporting in global comparison. J. Für Betr. 2012, 62, 45-84. [CrossRef]

55. Stittle, J.; Blas, M.; Conesa, I. Environmental reporting in Europe: An analysis of UK and Spanish developments. Eur. Bus. Rev. 1997, 97, 215-223. [CrossRef]

56. Kolk, A. Trajectories of sustainability reporting by MNCs. J. World Bus. 2010, 45, 367-374. [CrossRef]

57. Nunhes, T.V.; Bernardo, M.; José de Oliveira, O. Rethinking the way of doing business: A reframe of management structures for developing corporate sustainability. Sustainability 2020, 12, 1177. [CrossRef]

58. Venturelli, A.; Pizzi, S.; Caputo, F.; Principale, S. The revision of nonfinancial reporting directive: A critical lens on the comparability principle. Bus. Strategy Environ. 2020, 29, 3584-3597. [CrossRef]

59. United Nations Global Compact. The United Nations SDG Action Platform; United Nations Global Compact: New York, NY, USA, 2016.

60. UNCTAD. Guidance on Core Indicators for Entity Reporting on Contribution Towards Implementation of the Sustainable Development Goals; UNCTAD: Geneva, Switzerland, 2019.

61. World Economic Forum. Toward Common Metrics and Consistent Reporting of Sustainable Value Creation; World Economic Forum: Colony, Switzerland, 2020.

62. Carney, M. Breaking the tragedy of the horizon-climate change and financial stability. Speech Given Lloyd's Lond. 2015, 29, 220-230.

63. KPMG. The Road Ahead. The KPMG Survey of Corporate Responsibility Reporting 2017; KPMG: Amstelveen, The Netherlands, 2017.

64. GRI; Global Compact. Integrating the SDGs into Corporate Reporting. A Practical Guide; Global Compact: New York, NY, USA, 2018.

65. Adams, C.A. The Sustainable Development Goals, Integrated Thinking and the Integrated Report; Institute of Charteted Accountants of Scotland: Glasgow, UK, 2017.

66. IFAC. The 2030 Agenda for Sustainable Development: A Snapshot of the Accountancy Profession's Contribution; IFAC: Geneva, Switzerland, 2016; ISBN 9781608153145. 
67. Hahn, R.; Kühnen, M. Determinants of sustainability reporting: A review of results, trends, theory, and opportunities in an expanding field of research. J. Clean. Prod. 2013, 59, 5-21. [CrossRef]

68. Schramade, W. Investing in the UN Sustainable Development Goals: Opportunities for Companies and Investors. J. Appl. Corp. Financ. 2017, 29, 87-99. [CrossRef]

69. Pizzi, S.; Rosati, F.; Venturelli, A. The determinants of business contribution to the 2030 Agenda: Introducing the SDG Reporting Score. Bus. Strategy Environ. 2020, 1-18. [CrossRef]

70. Jensen, J.C.; Berg, N. Determinants of Traditional Sustainability Reporting Versus Integrated Reporting. An Institutionalist Approach. Bus. Strategy Environ. 2012, 21, 299-316. [CrossRef]

71. van der Waal, J.W.H.; Thijssens, T. Corporate involvement in Sustainable Development Goals: Exploring the territory. J. Clean. Prod. 2020, 252. [CrossRef]

72. Chen, S.; Bouvain, P. Is corporate responsibility converging? A comparison of corporate responsibility reporting in the USA, UK, Australia, and Germany. J. Bus. Ethics 2009, 87, 299-317. [CrossRef]

73. Business Call to Action-United Nations Development Program; GRI. Measuring Impact. How Business Accelerates the Sustainable Development Goals; GRI: Amsterdam, The Netherlands, 2016.

74. Fonseca, L.; Carvalho, F. The reporting of SDGs by quality, environmental, and occupational health and safety-certified organizations. Sustainability 2019, 11, 5797. [CrossRef]

75. GRI; UN Global Compact; PWC. An Analysis of the Goals and Targets; UN Global Compact: New York, NY, USA, 2018.

76. Dilling, P.F.A. Sustainability Reporting In A Global Context: What Are The Characteristics Of Corporations That Provide High Quality Sustainability Reports An Empirical Analysis. Int. Bus. Econ. Res. J. 2010, 9, 19-30. [CrossRef]

77. Skouloudis, A.; Evangelinos, K.; Kourmousis, F. Assessing non-financial reports according to the Global Reporting Initiative guidelines: Evidence from Greece. J. Clean. Prod. 2010, 18, 426-438. [CrossRef]

78. Isaksson, R.; Steimle, U. What does GRI-reporting tell us about corporate sustainability? TQM J. 2009, 21, 168-181. [CrossRef]

79. Pizzi, S.; Caputo, F.; Venturelli, A.; Adamo, S. Achieving sustainable development goals through non-financial regulation. First insights from the transposition of Directive 95/2014/EU in Italy. In Proceedings of the SIW 2019: Corporate Social Responsibility: Theoretical Analysis and Practical Implications, Naples, Italy, 6 November 2019; p. 12, ISBN 9788835103752.

80. Adams, C.A. The International Integrated Reporting Council: A call to action. Crit. Perspect. Account. 2015. [CrossRef]

81. Mervelskemper, L.; Streit, D. Enhancing Market Valuation of ESG Performance: Is Integrated Reporting Keeping its Promise? Bus. Strategy Environ. 2017, 26, 536-549. [CrossRef]

82. Lusk, E.J. Cognitive Aspects of Annual Reports: Field Independence/Dependence. J. Account. Res. 1973, 11, 191-202. [CrossRef]

83. IIRC. The International "IR" Framework; IIRC: Walles, UK, 2013.

84. Lai, A.; Melloni, G.; Stacchezzini, R. Corporate Sustainable Development: Is "Integrated Reporting" a Legitimation Strategy? Bus. Strategy Environ. 2016, 25, 165-177. [CrossRef]

85. Brammer, S.; Pavelin, S. Factors Influencing the Quality of Corporate Environmental Disclosure. Bus. Strategy Environ. 2008, 136, 120-136. [CrossRef]

86. Helfaya, A.; Moussa, T. Do Board's Corporate Social Responsibility Strategy and Orientation Influence Environmental Sustainability Disclosure? UK Evidence. Bus. Strategy Environ. 2017, 26, 1061-1077. [CrossRef]

87. Romero, S.; Ruiz, S.; Fernandez-Feijoo, B. Sustainability reporting and stakeholder engagement in spain: Different instruments, different quality. Bus. Strategy Environ. 2018, 28, 221-232. [CrossRef]

88. Rosati, F.; Faria, L.G.D. Business contribution to the Sustainable Development Agenda: Organizational factors related to early adoption of SDG reporting. Corp. Soc. Responsib. Environ. Manag. 2019, 26, 588-597. [CrossRef]

89. Izzo, M.F.; Strologo, A.; Granà, F. Learning from the best: New challenges and trends in IR reporters' disclosure and the role of SDGs. Sustainability 2020, 12, 5545. [CrossRef]

90. Creswell, J.W.; Creswell, J.D. Research Design: Qualitative, Quantitative, and Mixed Methods Approaches; SAGE Publications: New York, NY, USA, 2017.

91. Sandelowski, M.; Voils, C.I.; Knafl, G. On Quantitizing. J. Mix. Methods Res. 2009, 3, 208-222. [CrossRef]

92. Krippendorff, K. Content Analysis: An Introduction to Its Methodology; SAGE Publications: New York, NY, USA, 2018.

93. Matuszak, Ł.; Rózańska, E. CSR disclosure in Polish-listed companies in the light of directive 2014/95/EU requirements: Empirical evidence. Sustainability 2017, 9, 2304. [CrossRef]

94. Hayes, A.F.; Krippendorff, K. Answering the Call for a Standard Reliability Measure for Coding Data. Commun. Methods Meas. 2007, 1, 77-89. [CrossRef]

95. Craig, D. Introduction: The legitimising effect of socialand environmental disclosures-A theoretical foundation. Account. Audit. Account. J. 2002, 15, 282-311. [CrossRef]

96. The United Nations. The Decade of Action. Available online: https://www.un.org/sustainabledevelopment/decade-of-action/ (accessed on 5 October 2020).

97. Doni, F.; Bianchi Martini, S.; Corvino, A.; Mazzoni, M. Voluntary versus mandatory non-financial disclosure: EU Directive 95/2014 and sustainability reporting practices based on empirical evidence from Italy. Meditari Account. Res. 2019, $20-21$. [CrossRef]

98. Martinez-Blasco, M.; Garcia-Blandon, J.; Castillo-Merino, D. Are Investors Concerned by Annual Corporate Governance Reports? Some Evidence from the Spanish Stock Market. Eur. Manag. Rev. 2017, 14, 391-407. [CrossRef] 
99. De Cambourg, B.P.; Gardes, C. Ensuring the Relevance and Reliability of Non-Financial Corporate Information: An Ambition and a Competitive Advantage for a Sustainable Europe. 2019. Available online: http://www.anc.gouv.fr/files/live/sites/ anc/files/contributed/ANC/4.\%20Qui\%20sommes-nous/Communique_de_presse/Report-de-Cambourg_extra-financialinformations_May2019_EN.pdf (accessed on 22 January 2021).

100. Forestier, O.; Kim, R.E. Cherry-picking the Sustainable Development Goals: Goal prioritization by national governments and implications for global governance. Sustain. Dev. 2020, 28, 1269-1278. [CrossRef]

101. Stolowy, H.; Paugam, L. The expansion of non-financial reporting: An exploratory study. Account. Bus. Res. 2018, 48, 525-548. [CrossRef]

102. Red Española del Pacto Mundial de Naciones Unidas. Comunicado de Progreso 2019. Un Análisis de los ODS y los Diez Principios en las Empresas Españolas. Available online: https:/ / www.pactomundial.org/wp-content/uploads/2020/01/Comunicando-elProgreso-2019.pdf (accessed on 5 January 2021).

103. Szennay, Á.; Szigeti, C.; Kovács, N.; Szabó, D.R. Through the Blurry Looking Glass-SDGs in the GRI Reports. Resources 2019, 8,101 . [CrossRef] 